\title{
Get to Work or Go to Jail: State Violence and the Racialized Production of Precarious Work
}

Work requirements backed by threats of incarceration offer a fertile but neglected site for sociolegal inquiry. These "carceral work mandates" confound familiar accounts of both the neoliberal state's production of precarious work through deregulation and the penal state's production of racialized exclusion from labor markets. In two illustrative contexts — child support enforcement and criminal legal debt-demands for work emerge as efforts to increase and then seize earnings from indigent debtors; an ability to pay is defined to include an ability to work. In a third, demands for work are imposed directly through probation, parole, and other community supervision. In each context, the carceral state regulates work outside of prison. It defines appropriate labor conditions through concepts of voluntary unemployment, and it enables employers to discipline or retaliate against workers by triggering state violence. Additionally, mandated work may be removed from employment law protections when the carceral context dominates its sociolegal meaning. Finally, the resulting vulnerable workforces can be used to displace or discipline other workers not personally subject to carceral work mandates. Analogies to welfare work requirements, workplace immigration enforcement, and prison labor illustrate these points. Implications are considered for theorizing contemporary racial political economy.

"Hands Down! Go To Work!" read the signs raised by white counterprotesters (Gardner and Reuters 2014). They sought to rebut "Hands Up, Don't Shoot," the refrain of Black political mobilization after Michael Brown's killing by police in Ferguson, Missouri. The legibility of this exchange points to the practical and theoretical shortcomings of a "current moment [in which] anticapitalism and struggles against state violence and incarceration tend to be separate movements" (Kelley 2015, xix; cf. Dawson 2016). This programmatic essay identifies a class of neglected sociolegal phenomena in which avoiding state violence ("Don't Shoot!") is conditioned on performing labor discipline ("Go To Work!"). This phenomenon illuminates contemporary formations linking neoliberalism, the carceral state, and racial capitalism (Gilmore 2007; Robinson [1983] 2000; Wacquant 2009).

Noah D. Zatz is Professor of Law at UCLA School of Law. He can be contacted at zatz@law.ucla.edu. The author gratefully acknowledges the very helpful comments received from the anonymous reviewers and from the many colleagues and workshop participants who have kindly offered feedback over the long gestation of this article, too many, regrettably, to be enumerated here. Research for this article was supported in part by the Open Society Foundations and by the John Randolph Haynes and Dora Haynes Foundation. The analyses offered herein are the author's own and do not necessarily express the views of either the Open Society Foundations or the Haynes Foundation. 
"Go to work" reflects a recurring racial trope in the United States. The specter of insufficiently motivated Black or Brown workers both blames social distress on its victims and affirmatively justifies coercion into subordinated labor (Glenn 2002). Racialized institutional demands to "go to work" characterize recent "welfare reform" (Soss, Fording, and Schram 2011), but historically they are no stranger to the criminal legal system. Stretching well beyond prison labor and the convict lease (Haley 2016; McLennan 2008), police action and threats of incarceration have governed work by nominally "free labor" through such devices as vagrancy laws and debt peonage (Blackmon 2008).

Despite state-enforced labor subordination's centrality to slavery and Jim Crow, work is strikingly marginal to accounts of racial domination in today's "carceral state" (Beckett and Murakawa 2012; Hernández, Muhammad, and Thompson 2015). "Go away," not "go to work," is the decree typically attributed to mass incarceration, understood as a structure of mass exclusion from labor markets and containment of those excluded (Pager 2008; Simon 2007; Wacquant 2009). Troublingly, this focus on exclusion risks reproducing the trope of Black inactivity (Watkins 2014), especially when juxtaposed with robust analyses of how Latinxs and Asian Americans face racialized exploitation as workers (Gordon and Lenhardt 2007). In the latter context, state violence through immigration enforcement is widely understood to fuse exclusion from some jobs with subordination in others (Massey and Gentsch 2014; De Genova 2005).

In complementary fashion, "go to work" also finds no place in contemporary analysis of "precarious work" (Kalleberg 2011). The dominant narrative links bad jobs to a rising neoliberalism characterized by state withdrawal from effective labor market regulation (Grewal and Purdy 2015). Within that framework, the challenge for labor becomes figuring out how to get the state back in.

In the competing dynamic identified here, the state's capacity for violence inserts people into work, shapes the conditions of their labor, and transforms its meaning (Hatton 2018a; Tomlins 1995). Such an account builds on efforts to theorize neoliberal regulatory withdrawal together with the contemporaneous growth in policing, incarceration, and surveillance (Gilmore 2007; Wacquant 2009). It treats the carceral state as directly managing labor market activity, not only lying in wait for those cast out of work or erecting barriers to those entering it.

Three examples illustrate how major state institutions issue and enforce the ultimatum "get to work or go to jail" (Zatz et al. 2016): child support enforcement, collection of criminal fines and fees, and community supervision such as probation and parole. The first two translate claims for payment into demands for work. The third imposes work requirements directly while also reinforcing the first two. Each operates on a large scale and reflects the thorough racialization of both criminal legal institutions and economic inequality. By considering them together and analyzing their structural similarities, this article highlights the breadth and intensity of such work demands and also suggests how they may constitute a more general technique of "poverty governance" (Soss, Fording, and Schram 2011). Moreover, because these practices often are integral to policy reforms seeking "alternatives to incarceration" and combatting "barriers to employment," they may figure increasingly in new assemblages of welfare, treatment, and punishment (Hannah-Moffat and Maurutto 2012; Lynch 2012; Bumiller 2013). 
These carceral work mandates can regulate labor in four ways. They may define the conditions workers must accept, provide employers the power to trigger state violence against their workers, remove certain forms of work from employment law protections entirely, and displace or discipline other workers not directly subject to these mandates. Evidence on these points is currently fragmentary, reflecting the dearth of available research. Nonetheless, substantial analytical resources are available by analogy to welfare work requirements, workplace immigration enforcement, and prison labor, as well as the historical precedents noted above. What emerges is a roadmap for sociolegal research into how today's carceral state operates as a labor market institution not (only) through withdrawal or exclusion but also by enforcing subordinated inclusion (cf. Carbado, Fisk, and Gulati 2008; Seamster and Charron-Chénier 2017).

\section{A BRIEF REVIEW: PRECARIOUS WORK AND MASS INCARCERATION AS COMPLEMENTS}

The substantial literature on low-wage and precarious work largely adopts a narrative of de facto and de jure deregulation. Such deregulation achieves a more thoroughly marketized economy, denoted "neoliberal" (Kalleberg 2011; Grewal and Purdy 2015). This "ideological project and governmental practice mandating submission to the "free market' and the celebration of 'individual responsibility' in all realms" (Wacquant 2009, 1) has generated a "new class structure polarized by economic deregulation" (ibid., xvi). State withdrawal unleashes a "gloves-off economy" characterized by "employer strategies and practices that either evade or outright violate the core laws and standards that govern job quality in the U.S.” (Bernhardt et al. 2008, 2). Specific deregulatory mechanisms include the "fissuring" of the Fordist firm (Weil 2014) and declining state capacity to enforce what laws do apply (Bernhardt, Spiller, and Polson 2013).

Similarly, deregulation and underenforcement in capital and product markets, in international trade, and in international migration all unleash downward market pressure (Arup et al. 2006). Neoliberal politics also shreds the safety net (Wacquant 2009), weakening workers' bargaining power by intensifying the "work or starve" logic of capitalism (Piven and Cloward 1993; Wright 2004). All these analyses track traditional accounts of the welfare state as a democratic counterweight to market-driven inequality (Marshall 1950; Grewal and Purdy 2015).

Grounding precarity in unfettered markets assigns little role to racial politics. Race sorts people into different rungs of an occupational hierarchy without shaping its underlying structure (Kalleberg 2011, 52-55); discrimination runs counter to fundamental market logic (Kelman 2001). Critiques of precarious work thus risk erroneously taking neoliberalism "on its own terms, that is, presuming the primacy of economic forces and structures" (Robinson [1983] 2000, 299).

Race can enter the analysis by looking outside labor markets to other aspects of capitalist political economy, such as the ongoing role of "primitive accumulation" through slavery, neoslavery, and colonialism (Blackett 2011; Haley 2016; Robinson [1983] 2000). Today, that path connects racialized mass incarceration to prison labor (E. Smith and Hattery 2008), especially in private prisons (Davis 2000). But contemporary prison labor operates on a relatively small scale (Wacquant 2010; Gilmore 2007, 21), 
and focusing on it leaves untouched the swath of precarious work performed outside custodial contexts, though the two contexts certainly interact (Thompson 2011; Weiss 2001). Another approach centers racial politics within the adoption of neoliberal policies (Haney López 2013; Omi and Winant 2015) but still one step removed from the internal workings of the resulting labor markets.

Alongside the neoliberal shrinkage of the welfare state, however, state power has expanded massively through the criminal legal system (Wacquant 2009; Simon 2007). This includes not only incarceration but also policing and criminal legal supervision through front-end diversion and back-end noncarceral sentences like probation (Lynch 2012; Natapoff 2015; Phelps 2018; Kohler-Hausmann 2018). Here, thorough racialization is a central object of analysis (Alexander 2012; Western 2006).

These assertions of carceral state power typically are understood to operate outside or at the boundary of the labor market. Indeed, that spherical separation is essential to "neoliberal penality" (Harcourt 2011). Criminal legal institutions undermine access to jobs by disrupting employment, degrading skills, and "marking" people for stigmatization and exclusion based on past conviction, through both private employer screening and state occupational licensing restrictions (Pager 2008; National Research Council 2014). They thereby erect "barriers to employment" (Pager, Western, and Sugie 2009) at the border. Michelle Alexander indicts mass incarceration as an institution of racial caste because the New Jim Crow "permanently locks a huge percentage of the African American community out of the mainstream society and economy" (2012, 13).

Yet the old Jim Crow also thoroughly incorporated African American labor. Rather than representing a contradiction, such exclusion from better jobs reserved for whites complemented coercion into brutally exploitative ones. This system of subordinated inclusion relied heavily on criminal legal institutions extending well beyond direct sentences to "hard labor" on the chain gang or under the convict lease (Lichtenstein 1996; Childs 2015). Vagrancy laws criminalized unemployment and labor mobility (Goluboff 2007). Debt peonage flourished under criminal fraud statutes targeting workers who quit and under criminal surety systems that transferred criminal legal debts to private employers (Daniel 1972; Childs 2015).

Prison labor aside, subordinating labor inclusion is simply absent from leading accounts of how the contemporary carceral state shapes work (National Research Council 2014). Indeed, Wacquant identifies the disappearance of labor coercion as a distinctive feature of today's racial political economy: "What makes the racial intercession of the carceral system different today is that, unlike slavery, Jim Crow, and the ghetto of the mid-century, it does not carry out a positive economic mission of recruitment and disciplining of an active workforce. The prison serves mainly to warehouse the precarious and deproletarianized fractions of the black working class ..." (Wacquant 2009; cf. Simon 1993). The new carceral state regulates labor markets by managing, and masking, the consequences of labor market exclusion (Western and Beckett 1999; cf. Rusche and Kirchheimer [1939] 2003), not by applying the "work-enforcement strategy" characteristic of today's workfare state (Soss, Fording, and Schram 2011, 105). In this vein, "unemployed black men, along with increasing numbers of black women, constitute an unending supply of raw material for the prison industrial complex" (Davis 2000, 68), a "surplus population" available for profit not principally through labor but through the 
business of incarceration (Gilmore 2007, 72). This contains the otherwise restive "racial 'threat' [to] an ever-more confined and restricted zone of prosperity: the ostensibly 'civil' society of neoliberalism" (Omi and Winant 2015, 230). Again, border control, now managing those exiting rather than entering the labor market. ${ }^{1}$

These border control accounts provide an important corrective to the deregulatory understanding of precarious work. Locking workers out of one tier of the labor market can crowd them into a lower tier of worse jobs (Bumiller 2015; Peck and Theodore 2008; Augustine 2019). Similarly, criminal prohibitions on informal or illegal work may channel income-earning efforts into the conventional labor market (Wacquant 2009; Soss, Fording, and Schram 2011; Harcourt 2011). Throughout, however, the compulsion to work still originates in workers' need to put food on the table, not in edicts from the state: work or starve, not work or jail.

\section{CARCERAL WORK MANDATES IN THREE CONTEMPORARY CONTEXTS}

Child support enforcement, criminal legal debt collection, and noncustodial criminal legal supervision all confound standard accounts of neoliberal state withdrawal and carceral state labor exclusion. Each demands work under threat of state violence against people currently living outside state custody. This section explains how these "carceral work mandates" arise and reach a large swath of the population, especially among low-wage or unemployed workers. These mandates are meaningfully enforced, not paper tigers, and racial inequality structures both their imposition and their enforcement. This establishes the mechanisms and scale sufficient to plausibly shape worker and employer behavior. That sets the stage for the next section, which will analyze how carceral mandates can shape the work performed in their shadow, not through incarceration for noncompliance but through efforts to avoid incarceration by complying. The level and type of detail provided here is calibrated to that limited goal.

Carceral work mandates are defined by three criteria motivated by the preceding section. These criteria bring to the forefront common features that have been less salient in separate treatments of child support, criminal legal debt, and community supervision. This enables me to identify a more general form of interaction between the contemporary carceral state and labor markets, at a scale of analysis comparable to the leading border control accounts. ${ }^{2}$ Obtaining these benefits from "lumping" across several contexts necessarily sacrifices the attention to contextual differences that can be gained by "splitting," differences that matter to a complete account of each context. Thus, while I show that each involves carceral work mandates that share important

1. As with any analysis operating at this broad, structural scale, these border control accounts are subject to criticism for failing sufficiently to attend to differentiation and tension within such an aggregate as "the carceral state," across both jurisdiction and institutional role (prosecutors, police, judge, corrections officials, etc.) (Barker 2009; Pfaff 2017). This article engages these foils at a similar level of analysis, with similar limitations.

2. Two additional domains, not addressed here, that might be viewed through the lens of carceral work mandates are child removal to foster care, especially on grounds of parental neglect grounded in lack of income and employment (Roberts 2012), and mandatory work in civil confinement based on disability (Beckwith 2016). 
dynamics, I do not claim that these mandates constitute the dominant or fundamental nature of child support, criminal legal debt, or community supervision.

The first criterion is that incarceration here is prospective and conditional: a threat directed at "free labor," not people already in state custody. This differentiates prison labor, reaches a much larger potential scale, and extends carceral power into the heart of conventional labor markets.

Second, work is mandatory. This contrasts with how the carceral state can, and does, hinder or forbid work by erecting "barriers." It also differentiates workplace immigration enforcement against unauthorized workers who are legally barred from employment.

Third, these work mandates are enforceable through the state's direct exercise of physical violence. This distinguishes welfare work requirements enforced by withdrawal of economic support. Characterizing such economic sanctions as punitive, coercive, or criminalizing (Gustafson 2011; Hatton 2018a; Soss, Fording, and Schram 2011) offers important insights but also risks erasing by stipulation the distinction between welfare and carceral modes of governance. That institutionalized distinction is fundamental to the ideology of "free markets" and "free labor" (VanderVelde 1989; Pope 2010), one that treats the denial of financial assistance as government inaction relative to the common-law baseline of property and contract (Sunstein 1987) ${ }^{3}$ in contrast, involuntary servitude is imposed when someone is "forced to work by threat of criminal sanction" or "physical force" (United States v. Kozminski, 487 U.S. 931, 943 (1988)). Carceral work mandates bypass such distinctions and directly integrate the "right" (punitive/carceral) and "left" (social/economic) hands of the state (Wacquant 2009).

Situating these mandates within the overarching concept of state violence also allows a capacious but still grounded account of carceral governance. As other scholars have argued, identifying common features of "the strong state" (Simon 2014) that relies on physical power over bodies can enable analyses that link formal criminal sentences of incarceration to immigration detention and deportation, civil child support enforcement through contempt sanctions, street policing, and noncustodial forms of criminal supervision (Beckett and Murakawa 2012; Lynch 2012; Hernández, Muhammad, and Thompson 2015). Doing so avoids excessive analytical deference to the formal and manipulable boundaries of institutions the state itself denotes as "criminal" or "punitive" (Beckett and Murakawa 2012), even while those boundaries may mark significant differences in other respects, including legal practices organized around those formal boundaries.

\section{Child Support Enforcement}

Soon after Ferguson, a police officer in North Charleston, South Carolina, shot Walter Scott in the back as he ran from a traffic stop. Scott feared the officer would see an arrest warrant for Scott's nonpayment of child support (Robles and Dewan

3. Soss, Fording, and Schram emphasize the operation of "paternalist" welfare programs that "bolster these [economic] pressures with state authority" that "actively press[es participants] into accepting the worst jobs at the worst wages" $(2011,7)$. The disciplinary authority lying behind this activity, however, remains that of withdrawing assistance entirely. 
2015). The state's demand for child support also required that Scott get a job or go to jail, enforced by police action.

The work demands of child support enforcement reflect that system's deep ties to welfare (Brito 2012; Hatcher 2007). In its efforts to "privatize dependency" (Fineman 1995), the welfare state requires claimants to exhaust resources both from their own wage income and from their kin (Hays 2003, 19). A custodial parent's access to benefits requires several forms of child support cooperation, including signing child support claims over to the state so that it can seize payments to offset its benefits outlay. The state thus acquires a financial stake in nominally "private" obligations between co-parents (Hatcher 2007).

Front-line state and local child support enforcement operates under elaborate federal rules and infrastructure (Brito 2012). This apparatus emphasizes noncustodial parents of children receiving means-tested public assistance, but it applies to all child support cases. About thirteen million noncustodial parents are included in this sprawling system (Office of Child Support Enforcement 2016, Tbl. P-101).

Child support cooperation requirements for custodial parents quickly yield work requirements for noncustodial parents. Most often, both custodial and noncustodial parents have quite limited employment prospects (Sorensen and Zibman 2001). In 2003-04, 70 percent of all child support arrears were owed by noncustodial parents with annual incomes below $\$ 10,000$ (Sorensen, Sousa, and Schaner 2007). Among low-income fathers in arrears, a plurality are African American (Sorensen and Zibman 2001). Contrary to a middle-class divorce story centered on the "deadbeat dad," nonpayment (or underpayment) stems primarily from a lack of earnings to share, not a refusal to share the earnings in hand.

To make greater earnings available for payment, child support enforcement institutions directly demand work and evaluate work effort. For instance, the federal Personal Responsibility and Work Opportunity Reconciliation Act of 1996 (PRWORA), the primary Clinton-era welfare reform statute, contains a little-studied provision requiring that state child support authorities be empowered to "issue an order that requires" noncustodial parents to participate in "work activities" (42 U.S.C. § 666(a)(15)); these are defined by cross-reference to the provision establishing PRWORA's better-known work requirements for custodial parents receiving cash assistance.

This federal, welfare-related work enforcement infrastructure built upon older, less institutionally elaborate mandates. These include the standard enforcement tool of a "seek work order." For instance, an Illinois statute provides that when a child support obligor is unemployed, "the court may order the person to seek employment and report periodically to the court with a diary, listing or other memorandum of his or her efforts in accordance with such order," as well as to order participation in various workforce development programs (750 Ill. Comp. Stat. Ch. 5/505.1). This Illinois provision applies regardless of whether the supported child receives public assistance.

When a court directly orders an obligor to obtain work or participate in a "work activity," noncompliance can be enforced with contempt sanctions, including incarceration. Unlike welfare, in child support enforcement there are no payments from the state to cut off as leverage; instead, the state seeks to extract money from the noncustodial parent. 
Similarly, carceral sanctions ultimately enforce payment obligations themselves (Brito 2012). Civil debt collection is ineffective against people lacking assets, income, and credit. Using incarceration, or its threat, to collect has given rise to what many critics characterize as a new form of debtors' prison (Patterson 2008). Legally, incarceration for nonpayment is an available threat because traditional limitations on civil debt collection such as bankruptcy (Atkinson 2017) and bans on imprisonment for debt (Hampson 2016) do not apply. Child support obligations arise not from private contracts but from family court orders enforceable through contempt proceedings that can authorize incarceration (Patterson 2008). Additionally, all states criminalize some child support nonpayment (National Council of State Legislatures 2015).

Even without a direct work order, work requirements are embedded in the legal principles governing what formally is incarceration for nonpayment. Constitutional doctrine forbids incarcerating someone for being too poor to pay (Colgan 2014; Birckhead 2015). The legal touchstone is willful nonpayment: a choice not to pay despite the ability to pay.

Willful nonpayment includes willful failure to acquire the means to pay, mirroring the logic by which welfare means tests have long incorporated work and other behavioral considerations (Zatz 2012). New York courts routinely uphold incarceration for nonpayment, despite the obligor's present lack of funds, because "the ability to pay support also includes the ability to find employment" (Commissioner of Social Services v. Rosen, 736 N.Y.S.2d. 42, 44 (App. Div. 2001)). For the poor, voluntary unemployment supplies part of the content of willful nonpayment. Carceral child support enforcement thus runs on the same analytical engine that has long driven the welfare state: distinguishing voluntary from involuntary unemployment, the undeserving from the deserving poor (Handler and Hasenfeld 1991). Here, however, the baseline is lower: deservingness offers freedom from prison, not freedom from destitution.

The California Supreme Court illustrated these points in Moss v. Superior Court (950 P.2d 59 (Cal. 1998)), which reviewed a trial judge's decision to imprison a child support obligor for contempt. The obligor had neither hoarded funds nor refused any job offer. Instead, the high court held that unemployment itself constituted contempt where someone "fails or refuses to seek and accept available employment for which the parent is suited by virtue of education, experience, and physical ability" (ibid., 76). The trial judge had reasoned that the obligor surely "could get a job flipping hamburgers at MacDonald's [sic] ... He's, in my mind, chosen not to" (ibid., 63). ${ }^{4}$ Here the "criminalization of poverty" (Gustafson 2011) entails specifically the criminalization of unemployment.

The factual setting underlying Moss was no outlier. Scattered reports suggest that incarceration for nonpayment can be substantial in some jurisdictions (Brito 2012; Robles and Dewan 2015). Data from the Fragile Families and Child Wellbeing Study (FFCWS) support that conclusion at a national scale. The FFCWS is a longitudinal survey of mothers and fathers of a birth cohort of focal children, weighted to be representative of major cities in the United States (Reichman et al. 2001). Its detailed questions about child support obligations and enforcement reveal that, among

4. Although Moss adopted and elaborated upon the trial court's analysis, it declined to apply it to the obligor at hand because of retroactivity concerns. Other courts have applied similar principles (Zatz 2016). 
noncustodial fathers subjected to any child support enforcement action, at least one quarter were incarcerated for noncompliance during the nine-year follow-up period. Moreover, such incarceration affected 5 percent of all fathers (custodial or noncustodial) and an astounding 15 percent of all Black fathers (Zatz et al. 2016; cf. Cozzolino 2018). Thus, obligors facing work demands have every reason to take seriously the threat of incarceration, and this threat touches a substantial proportion of the workforce, especially in low-income communities of color.

Incarceration data alone cannot reveal whether and how state actors evaluated obligor work in the processes leading to incarceration. Given the prominence of work requirements within the legal and policy frameworks discussed above, however, they likely did in many cases.

Because these work obligations derive from payment obligations, work is not the exclusive means of compliance. Payment of the underlying obligation, sometimes as reduced to a "purge" amount deemed sufficient to escape contempt, will moot the work requirement. Those funds could be obtained not only through wages but also through charitable support, family contributions, or illicit activities (Haney 2018). This is not unlike other work mandates. For instance, in early twentieth-century peonage cases, criminal statutes offered workers indebted to their employers a three-way choice-work, pay, or go to jail. The jail sanction could be avoided through payment from nonwage sources (Zatz 2016). And in the welfare context, a custodial parent's access to alternate sources of income-including child support itself-will vitiate work obligations if that income substitutes for means-tested benefits payments. ${ }^{5}$

Thus, while there are additional dynamics of importance at play, work mandates are one significant feature of child support enforcement. When sanctions are sought against someone who does not pay, whether they are subject to incarceration will turn in important part on their work behavior. In addition to the general "ability to pay" concepts noted above, for instance, an Ohio statute explicitly provides that compliance with a seek-work order may provide a defense against sanctions for nonpayment (Ohio Rev. Code 3119.06(A)). ${ }^{6}$

These work requirements have until recently (Zatz 2016) largely been overlooked within the limited literature on child support enforcement and incarceration, primarily among legal scholars (Brito 2012; Cammett 2011; Patterson 2008; but cf. Chung 2011). This scholarship has focused principally on the actual imposition of incarceration (including procedural protections such as the right to counsel, which the Supreme Court addressed in Turner v. Rogers, 564 U.S. 431 (2011)) or on the child support

5. Relatedly, many system actors may be motivated ultimately by increasing payments, both to benefit custodial parents and the supported child and to offset public expenditures, not primarily by noncustodial parent work behavior as an end in itself. Welfare work requirements, too, often have been justified as means to ends of reducing public expenditures, raising standards of living, or setting good examples for children. These questions of motivation and effect (including effects outside of work) are relevant to a complete understanding and to normative assessment, but they do not alter the existence of work requirements.

6. This statute also reflects how work is embedded both in back-end compliance with existing support orders and in front-end establishment of the amounts of those orders. Nationally, support amounts routinely are set based on "imputed income" derived from the obligor's ascribed earnings capacity, even if persistently un(der)employed, and often subject to hard minimums regardless of that assessment (Brinig and Garrison 2018). Ohio's seeking-work defense applies only to these minimum support orders that reflect a prior judgment of severely limited earnings capacity; notably, even in such circumstances, the obligation to seek work remains. 
consequences of prior incarceration; Haney's sociological research recently united those perspectives (2018). Brito also notes how jailing obligors for contempt may disrupt future employment (2012), consistent with barriers analyses.

Conversely, the econometric literature on child support enforcement and employment has centered work but overlooked incarceration. It generally models child support enforcement exclusively as a tax on earnings (Miller and Mincy 2012; Cancian, Heinrich, and Chung 2013), without analyzing how nonwork is penalized. The dominant taxation model predicts employment disincentives, again cohering with a barriers analysis (Holzer, Offner, and Sorensen 2005).

The potential for child support enforcement to pressure obligors into work has, however, received attention in social policy circles. Lawrence Mead, the most influential conservative academic proponent of work-based welfare reform in the 1980s and 90s, has retooled his arguments to support analogous work mandates for noncustodial parents:

Raising poor men's work levels, like welfare mothers', will require some combination of help and hassle.... Even when opportunities are improved, a disorderly lifestyle must still be curbed before these men can take hold in the labor market and advance. So obligations to work, not just better chances, appear indispensable. $(2011,32)$

Notably, Mead's analysis is not specific to the child support system and its internal goals. Rather, he sees child support as one institutional lever for addressing what he conceptualizes as a broader social problem of inadequate labor discipline. That analysis explicitly invokes what Mead characterizes as a racial occupational pathology, of which child support nonpayment is merely one symptom: "Young black men will often refuse to work for 'chump change' even if it means not working at all. Or they accept jobs but then find them unrewarding or abusive, so they leave in a huff or are fired" (ibid., 18).

With work effort front and center, familiar issues from welfare-to-work reemerge, including disagreements about the causes of un(der)employment and disputes over voluntary versus mandatory employment services (Sorensen 2010; Mead 2010). Race persistently influences these domains (Brito, Pate, and Wong 2015), affecting the services offered, the work deemed "good enough," the value of caretaking that competes for time with paid work, and whether noncompliance is excusable or merits sanction (Bonds 2006; Roberts 1994; Soss, Fording, and Schram 2011).

Notably, the Obama Administration promoted, and often funded, child support work programs of the sort encouraged by the integration of custodial and noncustodial parent work requirements established by the 1996 PRWORA; this includes mandatory programs that expose obligors to contempt and incarceration for noncompliance (Turetsky 2012; Office of Child Support Enforcement 2014). ${ }^{7}$ Here is visible a potential bipartisan consensus around institutionalized work mandates broadly similar to, and building on, welfare reform; the differences are a pivot toward men and a shift from financial to carceral sanctions.

7. Simultaneously, the Administration sought other reforms not focused on work behavior, including ones that attempted to rein in payment obligations that exceeded obligors' ability to pay, especially during periods of incarceration. 


\section{Criminal Legal Debt}

Child support obligations have much in common with fines, fees, and restitution imposed by criminal legal institutions ("criminal legal debt" or "legal financial obligations" (LFOs)). The scholarship is fairly new (A. Harris, Evans, and Beckett 2010; Colgan 2014; A. Harris 2016), but the issue gained prominence after Ferguson (Civil Rights Division 2015) and has moved to the forefront of racial justice, criminal justice reform, and anti-poverty advocacy (Bannon, Nagrecha, and Diller 2010; Johnson et al. 2016). Those with outstanding debt likely number in the tens of millions (A. Harris, Evans, and Beckett 2010), reflecting and exacerbating broader race and class disparities in policing, prosecution, and sentencing.

Systematic empirical LFO research has focused on felony defendants (A. Harris 2016), but the Ferguson investigations and emerging research highlight LFOs accumulated through misdemeanors and lower-level traffic or public order violations (Natapoff 2015). When unpaid, these, too, can lead to arrest warrants and incarceration (Stuart 2011), as well as intermediate sanctions like driver's license suspensions. Both the underlying debt and subsequent arrests disproportionately burden low-income communities of color (Bingham et al. 2016). As with historical studies of convict leasing arising out of municipal courts (Haley 2016), incorporating attention to nonfelony LFOs both enlarges the population caught in their net and increases the representation of women (cf. Bumiller 2013).

Like child support obligations, LFOs typically are no ordinary civil debts. Instead, the payment obligation ultimately is enforced by the threat of incarceration (Beckett and Murakawa 2012; A. Harris 2016), whether through contempt, freestanding prosecution for failure to pay, or other legal devices. Again, carceral sanctions are governed by a "willful nonpayment" standard under both federal constitutional law and state statutes that limit incarceration to those lacking an "ability to pay" (A. Harris 2016; Zhen 2019).

As with child support, one way carceral work mandates arise is through the work effort judgments incorporated into "willfulness"/"ability to pay" analysis (Colgan 2017; Zhen 2019). To date, this nexus has received little scrutiny in the burgeoning advocacy and research around LFOs. Legal challenges (American Civil Liberties Union 2018; Equal Justice Under Law 2018) have focused on widespread "auto-jail" practices (A. Harris 2016) where nonpayment triggers incarceration without any individualized assessment of ability to pay. Tellingly, a recent LFO "ability to pay" lawsuit against the Los Angeles Superior Court sidestepped the issue by choosing plaintiffs receiving disability benefits premised on inability to work (Holland 2016).

Today's campaigns against the "new debtors' prisons" keep the work question at bay by treating inability to pay as a fixed status: those incarcerated for nonpayment suffer this fate "simply for being poor" (Bannon, Nagrecha, and Diller 2010, 21). Poverty status is separated from economic conduct, replicating the pattern of early welfare rights advocacy (Zatz 2012). This income/behavior distinction likely will come under pressure if "ability to pay"/“willful nonpayment" determinations become contested in practice. The concern will be "to ferret out which people ... are not employed ... because they don't want to be employed or [instead] because they can't find work" (A. Harris 2016, 137). In this way, criminal legal debt offers a new stage for the "sturdy beggars" 
(Handler 2004, 277) who have long haunted social welfare policy and whose invocation both reinscribes the work ethic and attributes poverty and criminal legal involvement to racialized personal pathology (Gans 1994; Gustafson 2013).

Several sources indicate how the work issue sits just below the surface, latent in the "ability to pay." The relatively sparse LFO statutory provisions defining "ability to pay" sometimes refer to earnings capacity and future employment, not just present income (for example, Cal. Veh. Code $§ 42003$ ), again echoing the better-established child support practice of setting orders based on imputed income. Although not focused on this point, Alexes Harris's study of criminal legal debt found that corrections officers, prosecutors, and judges explicitly invoke judgments about work effort when determining whether nonpayment was willful (2016). One opined, in a statement mirroring the Moss trial court opinion, that "all nonpayment is willful because felons 'can always go out and get a day job”" (A. Harris, Evans, and Beckett 2010, 1788 n. 28).

Indeed, such inquiries are invited by the touchstone of LFO "ability to pay" jurisprudence, the Supreme Court's Bearden v. Georgia opinion (461 U.S. 660 (1983)). Bearden allowed incarceration only when a defendant "willfully refused to pay" or "failed to make sufficient bona fide efforts legally to acquire the resources to pay" (ibid., 672), including "efforts to obtain employment" (ibid., 674). Post-Bearden cases illustrate both this payment-work nexus and its intrinsic incorporation of work effort judgments. One Utah case, for instance, upheld incarceration for willful nonpayment of criminal restitution because the defendant, although employed full-time, did not take on a second job (State v. Brady, 300 P.3d 778 (Utah Ct. App. 2013)); the second job was necessary to enable payment because his existing earnings were largely devoted to paying child support. ${ }^{8}$

Although the LFO context shares with child support enforcement these work mandates emergent from ability-to-pay jurisprudence, it currently differs in that the authorizing statutes rarely confer explicit authority to order defendants to seek and maintain employment. The same result, however, often is achieved when criminal legal debt payment obligations are supervised via probation or parole, which themselves incorporate direct work mandates, as discussed in the next section.

Nor have mandatory job search, placement, and training programs been widely promoted and institutionalized in the LFO context to the extent seen in child support enforcement during and after the work-based welfare reform efforts of the 1990s. Nonetheless, seeds have been planted. New Jersey, for instance, in the late 1980s operated a policy experiment called "MUST Earn Restitution" that mandated job search and training as part of an effort to increase LFO payments under threat of incarceration. (Weisburd, Einat, and Kowalski 2008). In the 1970s, some states experimented with "restitution center" residential programs that incorporated mandatory private sector work in furtherance of payment (Temporary State Commission on Management and Productivity in the Public Sector 1977). These arose in the wake of court decisions that relied upon the Thirteenth and Fourteenth Amendments to strike down schemes that incarcerated defendants to force them to "work off" their LFO debts via prison labor (Anderson v. Ellington, 300 F. Supp. 789 (M.D. Tenn.

8. The court also faulted the defendant for not obtaining a loan from a family member, highlighting how, as with child support, the ultimate emphasis on payment means that work is not the sole concern. 
1969); Williams v. Illinois, 399 U.S. 235 (1970)). Mississippi currently operates four such restitution centers (Mississippi Department of Corrections 2019).

Although direct mandates of private sector employment are not currently widespread, another type of work mandate already receives substantial attention in LFO policy: unpaid community service. Rather than ordering defendants to "work off' LFOs in jail, some states shifted toward mandating service on public works projects or for nonprofit entities in lieu of cash payment. ${ }^{9}$ Today's liberal reformers often have embraced court-ordered community service as an "alternative to incarceration" for nonpayment (Bannon, Nagrecha, and Diller 2010). If the LFO problem presents a dilemma as between debtors' prison and paying ransom, then work seems to offer a third way. Debtors' prison can be converted into debt peonage. As Gilmore warns, "debt robs. But debt also disciplines" $(2011,260)$. This conversion is generally absent from critical accounts of criminal legal debt that place financialization at the center of its distinctly neoliberal character (Page and Soss 2017).

Even critiques of debtors' prison that explicitly invoke peonage (Birckhead 2015) often, though not always (Murch 2016), miss the potential for racialized control and economic extraction mediated by labor rather than payment. Instead, the downside of community service is seen only as potential new "barriers to employment" (Birckhead 2015; A. Harris 2016), missing the labor involved in community service itself.

Promoting work mandates as an alternative to incarceration for nonpayment is a path already worn by child support policy (Turetsky 2012). When promulgating new child support regulations, the Obama Administration distinguished sharply between orders to pay and orders that "require certain actions by the obligor, such as obtaining employment or participation in job search or other work activities." Treating noncompliance with these orders as contempt punishable by incarceration is deemed suspect for nonpayment but appropriate for nonwork because there "the obligor has the present ability to do what is ordered of him or her" (Office of Child Support Enforcement 2014, 68557).

Like the presumption that McDonald's stands ready to hire all the world's unemployed (Brito, Pate, and Wong 2015), the creation of court-ordered community service "opportunities" enables all nonpayment to be characterized as voluntary insofar as the defendant has "chosen" not to work off his debt. Vice versa, debtors are told quite bluntly, go to work (for free) or go to jail (City of Wichita v. Lucero, 874 P.2d 1144 (Kan. 1994)). Even if the specific form of community service comes under criticism, the likely alternative will be variations on the basic formula of work requirements, albeit with a broader menu of specific "work activities" more akin to the welfare work regime. In 2017, for instance, a new Louisiana statute began allowing LFOs to be discharged, at the supervising authorities' discretion, by "payment alternatives" including "substance abuse treatment, education, job training, or community service" (Louisiana C. Cr. P. $\S$ $875.1(\mathrm{D})(2)(\mathrm{c}))$.

9. Examples from Thirteenth Amendment challenges to this practice include State ex rel. Carriger v. City of Galion, 560 N.E.2d 194 (Ohio 1990); Traylor v. State, 458 A.2d 1170 (Del. 1983); Opinion of the Justices, 431 A.2d 144 (N.H. 1981); Community Service of Work Projects in Lieu of Payment of Court Costs, Tenn. Op. Att'y Gen. No. 99-233 (Dec. 15, 1999). 


\section{Community Supervision}

Carceral work mandates also arise from probation, parole, and other forms of noncustodial ("community") criminal legal supervision. In any given year almost five million people, mostly people of color, are under post-sentence community supervision (Kaeble, Maruschak, and Bonczar 2015), largely through "mass probation" (Phelps 2018). Supervision also emerges from front-end "diversion" programs that defer prosecution or conditionally dismiss a conviction pre-sentence (Lynch 2012; KohlerHausmann 2018), as well as through pretrial alternatives to money bail (Steinberg and Feige 2015). In each case, behavioral conditions are the price defendants pay to avoid incarceration. Violations of those conditions may not constitute a freestanding criminal offense, and they may be established without the procedural protections applicable to convictions (Beckett and Murakawa 2012).

Seeking and maintaining employment is a ubiquitous condition of supervision for both probation and parole. Indeed, it is among the most common (Doherty 2015; Petersilia 2003; L. F. Travis and Stacey 2010), though recent research gives this little sustained attention (Petersilia 2003; J. Travis 2005; but cf. Simon 1993). Thus, incarceration may result from an insufficiently vigorous job search, an inappropriate refusal of a job offer, or an unjustified quit (Gurusami 2017). ${ }^{10}$ Technically, that incarceration punishes the underlying offense of conviction. As a practical matter, though, the sanction is triggered by failure to work to the state's satisfaction, much as we saw with child support enforcement formally characterized in terms of nonpayment but nonetheless explicitly contingent on work.

James Nolan's research offers a vivid example:

A participant in Judge McKinney's Syracuse, New York drug court lost his job. McKinney called the employer and learned that the client was regarded as a "damn good employee" and that the boss would "hire him back in a heartbeat" if the judge could guarantee that he was drug free and that he wouldn't miss any work. So the judge ... said to [the employer]: "Okay, I'll make a deal with you, you take him back and I'll add another weapon to your arsenal. If he doesn't come to work when he is supposed to, ... if he comes to work under the influence of any kind of drugs, I'll put him in jail, on your say so." $(2002,32)$

One survey of hundreds of drug courts found employment or education requirements the second most common condition after drug treatment; community service mandates also were widespread (Rossman et al. 2011).

Again, relatively little is known about the nature or degree of street-level enforcement of these conditions. Research from the early 1990s reported minimal enforcement (Simon 1993), but recent case studies cite employment pressure from parole and probation officers as a major feature of supervisory relationships (Gurusami 2017; Augustine 2019). Moreover, data from the 2004 Survey of Inmates in State and

10. See, e.g., United States v. Woodson, 463 F. App'x 266 (5th Cir. 2012); State v. Archuleta, 812 P.2d 80 (Utah Ct. App. 1991). 
Federal Correctional Facilities and the 2002 Survey of Inmates in Local Jails suggest that work-related carceral threats are carried out at nontrivial rates (Zatz et al. 2016). At any one time, about nine thousand individuals nationally report being incarcerated for violating a probation or parole employment condition, consistent with findings from other sources (Petersilia 2003, 151). These work rule violations often coincided with those for failure to pay, while another eight thousand cases formally involve only nonpayment, which we have seen also implicates work. Among the twelve hundred cases based exclusively on work rule violations, two-thirds of respondents reported having worked full-time in the month preceding admission. Their work, however, appears to have been intermittent and/or very low-wage, ${ }^{11}$ suggesting that work enforcement was regulating the nature and intensity of employment, not bare labor market participation. Notably, already stark racial disparities in probation and parole incarceration generally (Phelps 2018) were further intensified for work condition violations, with Black defendants representing 42 percent of the former and 67 percent of the latter.

Data on incarceration for violations does not capture those who comply with work demands but nonetheless are affected by them, including by accepting labor conditions they might otherwise resist (Hatton 2018a). One possible indicator of such effects is an anomaly in the literature on post-incarceration employment: despite the well-known barriers erected by a criminal record, recently released prisoners initially work at rates above their pre-incarceration levels (Pettit and Lyons 2007; Loeffler 2013). Pettit and Lyons suggest in passing that this increase might reflect post-release supervision enhancing earnings capacity. Yet employment increases also could arise if work mandates created pressure, above and beyond financial incentives, to accept jobs that might previously have been forgone (Bumiller 2013; Augustine 2019). The latter coheres better with Pettit and Lyons's other finding that wage rates decreased immediately post-release. ${ }^{12}$ Other research found that the threat of probation revocation, not employment services, explained a program's entire effects, though in that case only payments and not earnings were measured (Weisburd, Einat, and Kowalski 2008).

Work mandates under community supervision may increase in importance alongside policy attention to "reentry" (Petersilia 2003; J. Travis 2005). Mead, for instance, touts probation and parole as, like child support enforcement, potentially powerful institutions with underutilized capacity to impose and inculcate labor discipline among low-income men of color (2011). He advocates incorporating mandatory work programs like those developed for welfare-to-work (cf. J. Travis 2005; Simon 1993, 263) and then child support enforcement. As with welfare reform, many liberals may agree, leaving policy disputes confined to the familiar balance between punitive "hassle" designed to lower expectations and supportive "help" designed to increase the returns to work (Mead 2010; Sorensen 2010). Underlying this agreement is the widespread view that employment is a foundation of personal and community flourishing (Wilson 1996), specifically including avoidance of future criminal legal system

11. Among employment violators who provided income data, two-thirds reported income below $\$ 800$ in the month prior to admission.

12. It has been suggested (National Research Council 2014), without specific evidence, that such employment effects could be explained by substitution of formal for informal work, to which would also have to be added the sacrifice of a wage premium for informality. One recent study of child support work mandates found no evidence of this mechanism (Zatz and Stoll forthcoming). 
involvement (Uggen 2000). Sugie recently has noted, however, that the extremely precarious nature of some work available to recently incarcerated people "likely exacerbates day-to-day instability and strain" (2018).

Bruce Western, for instance, sharply criticizes how mass incarceration generates racial and labor market inequality (2006) and proposes massive annual spending on transitional jobs and other supports for recently released people (2008). Nonetheless, like Mead, he would incorporate work mandates into parole. Despite opposing full revocation for technical violations, Western endorses "short jail stays up to several weeks" $(2008,19)$ to sanction nonwork (cf. J. Travis 2005). These would enforce work discipline and instill "rudimentary life skills of reliability, motivation, and sociability with supervisors and coworkers" (Western 2008, 14), echoing Mead's focus on a "disorderly lifestyle" (2011, 31) and "breakdown in work discipline" $(2011,16)$. Likewise, the widely celebrated Center for Employment Opportunities (CEO) model provides transitional employment to instill "the habits and competencies that make for a good employee emphasized through the routine of reporting for work each day, cooperating with colleagues, and following supervisors' directions" (Broadus et al. 2016, iii). Participants enter through parole or probation officer referrals and sometimes are specifically mandated to participate (Redcross et al. 2012).

Work requirements are only one component of community supervision and may operate in synergy with conditions mandating payment of child support (Haney 2018) or criminal legal debts, community service, or other mandatory programs. Forrest Stuart has shown how diversion programs in Los Angeles' Skid Row leverage quality-of-life arrests into mandatory participation by unhoused people in residential social services they previously had avoided (2011). Although Issa Kohler-Hausmann suggests that the content of such programs is unimportant, with community service functioning as a "neutral currency of hassle and performance capacity" (2018, 230), Stuart's analysis points toward the broader political economy in which they are situated: in these programs "arrestees also constitute the manual labor-maintenance, cleaning, and food preparation-necessary to keep the facility's operating costs to a minimum" (2011, 208). Similarly, recent investigative journalism has revealed a more extreme practice of Oklahoma courts mandating, as conditions of probation or diversion, participation in what are denoted residential drug treatment but in practice consist primarily of forced labor for commercial poultry processing plants (A. J. Harris and Walter 2017). The result was both a captive labor force for the plants and a revenue source for the programs, obviating any need for either public funding or participant payment.

\section{REGULATING WORK UNDER CARCERAL THREAT}

The previous section demonstrated that threats of incarceration for nonwork are widely institutionalized and meaningfully enforced. This one explores how these institutions shape the nature of work for the compliant, not only how they repress nonwork (Soss, Fording, and Schram 2011; Hatton 2018a). I focus on the material conditions of work and power relationships within workplaces, conceptualizing carceral work mandates as unconventional forms of labor and employment law. Four forms of work regulation are implicated here: downward pressure toward minimum labor standards, 
enhancing employer power in workplace disputes, redrawing the boundaries of legally protected employment, and displacing or disciplining other workers not directly subject to the carceral threat. The first three dynamics are illustrated, respectively, by comparison to welfare work requirements, workplace immigration enforcement, and prison labor, and the fourth by all three. The potential for each dynamic can be seen across all three sources of carceral work mandates-child support enforcement, criminal legal debt, and community supervision-discussed above, affirming the value of conceptualizing them as instances of a general form.

\section{Depressing Labor Standards by Defining Voluntary Unemployment}

Conventional employment law sets labor standards by establishing a floor beneath which employers may not go. The purpose and, where enforced, effect is to raise working conditions at least to that floor. Work requirements also set labor standards and shape conditions but in a different way. Most simply, they penalize nonwork. For some people who would not work absent the threat of penalty, the threat pushes them to work instead. Schematically, the threat lowers reservation wages. Likewise, bargaining power is lost among workers who absent the carceral danger could credibly threaten to quit if the employer cut (or refused to raise) wages. For both reasons, wages decline. This is essentially the old logic of "less eligibility" (Rusche and Kirchheimer [1939] 2003; Handler and Hasenfeld 1991), which calibrates the conditions of nonwork (whether set by public benefits or prison conditions) to sit below those deemed appropriate for work.

This simple model leaves out the process of defining the "nonwork" that triggers the penalty and the "work" that avoids it. That process directs the administration of work requirements toward the characteristics of jobs. This connection flows through the voluntary/involuntary unemployment distinction. For someone deemed unable to work, nonwork triggers no penalty. That is why work requirements - in the classic public benefits context and in the carceral ones discussed here (State v. Ingram, 142 P.3d 338 (Kan. Ct. App. 2016); People v. Likine, 823 N.W.2d 50 (Mich. 2012)) —always are restricted to people variably described as "employable," "able-bodied," "not disabled," and the like, complicated and normatively charged as those categories turn out to be (Diller 1996). ${ }^{13}$

The most difficult challenges arise from assessing the voluntariness of unemployment for people who are deemed "employable" in the abstract. If there are no jobs available, unemployment is "involuntary." 14 But which jobs count? For instance, is a job "available" if it requires a long commute or even a cross-country move? For Social Security disability purposes, yes; for most unemployment insurance purposes, no.

13. The futility of treating employability or job availability as absolutes, rather than judgments about the burdens appropriate to bear, is illustrated by cases where old age or disability justify nonwork for the purpose of public benefits eligibility but are deemed insufficiently severe to defeat carceral work mandates (Andreozzi v. Andreozzi, 813 A.2d 78 (R.I. 2003); Schmeets v. Turner, 706 S.W.2d 504 (Miss. Ct. App. 1986)).

14. Even here, many states deem incarcerated people "voluntarily" unemployed for child support purposes because of their responsibility for the underlying criminal offense (Haney 2018). 
What about a job entailing illegal working conditions: subminimum wages, subjection to sexual harassment, or safety hazards? Generally speaking, a worker may choose to refuse such jobs and yet still be considered involuntarily unemployed. That much is clear in the public benefits context (Zatz 2006), and it would be surprising to find something different with carceral work requirements (but cf. Schmeets v. Turner, 706 S.W.2d 504 (Miss. Ct. App. 1986)). The distinction between voluntary and involuntary employment is a thoroughly normative one (Williams 1999). ${ }^{15}$

The classic criticisms of the unemployed are that they are being too choosy by rejecting some jobs and too lazy by settling for inadequate jobs or no job at all. Recall Mead's complaints about refusals to work for "chump change" (2011, 18). Thus, actual work requirements do not simply demand work in the abstract. They enforce expectations that the un(der)employed worker search harder, work longer, and accept less (Lafer 2004). One child support obligor, for instance, was found in contempt, despite working forty hours per week, because he declined an opportunity to earn more by working "ten to fifteen hours per day, sometimes seven days per week," in a different job that required relocating to another state $(\mathrm{McDaniel} v$. McDaniel, 878 So. 2d 686, 690 (La. Ct. App. 2004)); Haney reports one child support judge held obligors to the standard set by a father who worked four jobs and mowed lawns to boot (2018). Gurusami found probation officers pressuring people to abandon part-time or temporary work to pursue full-time work even while condemning as "lazy" attempts to enhance employability through education $(2017,445)$. Thus, not only does some nonwork avoid sanction, but some work may be deemed noncompliant.

The same basic points apply to unemployment through job loss. A worker who quits may be deemed voluntarily or involuntarily unemployed depending on the reasons for quitting. Recall Mead's complaint about "leav[ing] in a huff" merely because the job is "unrewarding" $(2011,18)$. So, too, for terminations, depending on the worker's responsibility: one obligor went to jail because he got fired for fighting with a coworker (Batton v. Com. ex rel. Noble, 369 S.W.3d 722 (Ky. Ct. App. 2012)).

If carceral work mandates have any effect, they must exert downward pressure on labor standards. In principle, all actually existing nonwork could be deemed "involuntary," but that obviously is not the point. Rather, the rationale is that too many workers are shirking their responsibilities and need the firm hand of state power to whip them into shape (Mead 2011).

This combination of increased employment at lower wages has been found in research on welfare (Cancian et al. 2002), parole (Pettit and Lyons 2007; cf. Haley 2016, 185), and, more tentatively, child support work requirements (Schroeder and Doughty 2009). Sugie's research on recently incarcerated job-seekers also suggests how this downward ratchet could operate. More extensive employment was a function not of better opportunities but rather greater "willing[ness] to take on poorer quality work"; those who worked more reported worse hours, pay, and overall conditions than those who worked less $(2018,1478)$. Other research also finds sectors where employers will

15. Similarly, it is of little moment that a worker's choice about accepting a job is sensitive to increased pressure. If refusing an unduly dangerous job is consistent with deeming unemployment involuntary when no other work is available, later accepting that job with a gun to one's head does not undermine the original conclusion. 
hire formerly incarcerated workers, so long as they accept abusive conditions (Bumiller 2015; Peck and Theodore 2008). One function of carceral work mandates is to manufacture that willingness to accept less.

Such downward pressure, however, is not unlimited. And that limit could be set somewhere above the floor established by conventional employment protections. For instance, employers generally are permitted to impose mandatory overtime, so long as it is properly compensated; nonetheless, welfare work requirements typically prohibit agencies from mandating more than forty-hour work weeks (Zatz 2006). So a worker could be fired legally, based on her choice to refuse overtime, and yet be deemed involuntarily unemployed and thus compliant with work requirements. Longstanding points of legal conflict involve whether it is excusable to refuse a transfer that would require a long-distance move (required by McDaniel, supra), to miss work or restrict availability in order to care for an ill family member or a young child, and so on (Williams 1999).

Similarly, workers may be able to limit their search to their chosen occupation, one that they have trained for, or for wages commensurate with their prior experience. Such restrictions traditionally are incorporated into unemployment insurance's "suitable work" concept; those protections often weaken as time passes and unemployed workers are expected to lower their standards and accept downward mobility (Nicholson and Needels 2006). Similar concepts, without much calibration, are echoed in the California Supreme Court's Moss opinion limiting child support obligors' work expectations to "employment for which the parent is suited by virtue of education, experience, and physical ability" (950 P.2d 59, 76 (Cal. 1998)).

The bounds of "involuntary unemployment" can vary significantly with legal context. While unemployment insurance allows workers temporarily to hold out for jobs comparable to their previous work, "Work First" or "Labor Force Attachment" programs in the welfare-to-work context enforce the notion that any (legal) job is better than no job. In a Portland welfare-to-work program often touted as an alternative to "Work First," a key feature was allowing participants to hold out for jobs with supra-minimum wages and some prospect of advancement (Berlin 2002). Notably, the Obama Administration's child support enforcement regulations initially rejected funding "services to promote access to better jobs and careers" and instead prioritized "rapid labor force attachment" programs that take labor market prospects as-is (Office of Child Support Enforcement 2014, 68558). The Michigan Supreme Court recently justified its especially stringent "impossibility" standard for involuntary unemployment by referencing the child support context's specific "concern for paying the debt one owes to one's child, which arises from the individual's responsibility as a parent" (People v. Likine, 823 N.W.2d 50, 70 (Mich. 2012)).

Just as some conception of what jobs are good enough is intrinsic to "involuntary unemployment," so too is some conception of what life is good enough for the worker: what standard of living is sufficient, how much time should be devoted to work, what level of stability or uncertainty is acceptable, with what consequences for family members, and so on. Such conceptions of appropriate work and life invite interpretations shaped deeply by the race, class, and gender positions of the worker. Although the particularities have varied, racial labor hierarchy long has been justified by attributing lesser material needs to workers of color, greater need for strict discipline, and 
unsuitability to higher status work (Glenn 2002; Lamont 2000; Davis 2000); it also is sustained by "colorblind" disregard of racialized barriers to employment (Brito, Pate, and Wong 2015). At a micro level, decision makers must "apply a logic of appropriateness to the events that unfold at their desks (asking what is permissible, reasonable, and right to do in a case such as this), they must assign meaning to a client's action-treating it as a fluke, an avoidable mishap, or an intentional act of noncompliance and deceit" (Soss, Fording, and Schram 2011, 300). The racial content of such decision making is amplified by the institutional context in which such judgments are made (Soss, Fording, and Schram 2011). We are considering, after all, workers already defined in various combinations by debt, by nonmarital childrearing, by criminal conviction.

A striking feature of carceral work mandates is the minimal formal elaboration of these suitable work concepts. Child support work requirements sometimes do come with limitations, such as "employment commensurate with the obligor's education, training, professional or occupational qualifications, job skills, work history, and the availability of employment opportunities in the community" (56 Okla. St. Ann. § 240.10(B)(5)). Even these have far less detail than typical of public benefits contexts, and they sometimes impose such broad obligations as obtaining "any employment that the obligor is capable of performing” (Mont. St. Ann. § 40-5-291(1), (5)). In the criminal legal debt and community supervision contexts, however, there is virtually no formal guidance in statute or case law.

The lack of authoritative standards does not mean that lines are not being drawn. It simply affects which institutional actors are drawing them. The implication is that labor standard setting is currently submerged in the discretion of traffic court judges, child support enforcement agencies, probation officers, and the like (Gurusami 2017; Haney 2018; A. Harris 2016). The discretion, and resulting interpersonal power, of street-level bureaucrats (Lipsky 1980) is itself an old theme in the public benefits literature on work requirements (Handler 2004; Brodkin 1997).

\section{Empowering Employers to Trigger Carceral Enforcement}

Carceral work mandates also confer on employers power over workers at moments of potential exit. This shapes the ongoing practice of workplace governance and discipline. What happens when employers and workers conflict over working conditions, job performance, and so on? The employer's day-to-day economic power normally comes from its ability to fire workers and cut off their wages. That power expands in both kind and degree when the employer also can threaten to get the worker arrested, an instance of what Hatton terms "social coercion" more generally (2018a).

The analogous point has been developed regarding employers' ability to trigger immigration enforcement, which gives them a potent means of retaliating against immigrant workers for workplace complaints, union organizing, or the like (R. Smith, Avendaño, and Martínez Ortega 2009). The analogy may seem curious because, for unauthorized workers, the state forbids work rather than mandating it. But the crucial insight concerns an employer's control over bringing down the power of the law, not the formal content of the law's command. Because the state relies on employers as delegated immigration screeners (Lee 2009), employers can hire unauthorized workers and 
then hold over them the threat of triggering detention and deportation with a simple call to Immigration and Customs Enforcement (ICE) (Kim 2015).

Employers' ability to leverage state violence is even clearer with employer-specific guestwork visas. Because any rupture in the employment relationship can trigger deportation, guestwork programs have long been criticized for creating a relationship akin to involuntary servitude (Ontiveros 2006; Gordon 2006). Indeed, the Supreme Court's peonage jurisprudence equates a regime that "authorize[s] the employing company to seize the debtor and hold him to the service" with one that enlists "the constabulary to prevent the servant from escaping, and to force him to work out his debt" (United States v. Bailey, 219 U.S. 219, 244 (1911)). Either way, the day-to-day power relations at work operate in the shadow of what workers can expect from defiance or departure (Pope 2010).

Employers gain similar power when carceral work mandates merge the employer's supervisory interests with those of the mandating institution (cf. Levin 2018). In the drug court episode recounted above, Judge McKinney offered to "add another weapon to [the employer's] arsenal" by promising to "put him in jail, on your say so" (Nolan 2002). Similarly, in the early twentieth century, "[p]aroled black women who performed domestic service for white employers were always under the threat of being sent back to the chain gang or state farm if they broke a rule or failed to work up to their employers' standard" (Haley 2016, 176), and employers stayed in close touch with criminal legal authorities (cf. Simon 1993). Today, one reentry program in Louisiana touts itself to employers as providing "Oversight: Probation Officers and Case Managers are your HR Department."16

In principle, a worker's vulnerability would be limited by the "involuntary unemployment" concepts discussed above. But disputes over working conditions often are murky. As an early peonage case explained, state coercion survives legal protection for quitting with "sufficient excuse" because that protection "could never be known to be available except at the risk of, and at the end of, a criminal prosecution" (Toney v. State, 37 So. 332, 334 (Ala. 1904)). This is particularly true where workers under carceral threat already have been rendered suspect by the intersection of formal legal status and race (Soss, Fording, and Schram 2011, 80). Authorities may find credible employers' accounts of insufficient willingness to work on their terms and may crack down based on employers' "say so."

\section{Creating Legally Unprotected Forms of Work}

The previous two sections assumed that the carceral threat could drive labor standards down toward the legal floor but not below it, underenforcement aside. Those floors, however, generally apply only to work legally recognized as employment. Carceral work mandates also may operate to remove that floor by enabling the legal classification of work as outside employment. The result is a new tier of subordinated labor subject

16. New Orleans Education League of the Construction industry, Staffing Solutions for the Residential Construction Industry (n.d.). Observed and communicated to the author by Kelly Orians, New Orleans, October 2017. 
simultaneously to enhanced coercion and diminished protection. This comports with longstanding patterns by which the labor citizenship associated with white, male breadwinners has been dissociated from work deemed to occur outside the labor market and, instead, to be embedded legally in separate institutional spheres of family, of immigration, of welfare, and/or of criminal law (Dawson 2016; Gilmore 2007, 185; Hatton 2015; Zatz and Boris 2014).

Prison labor illustrates this dynamic. US courts place it outside protected employment relationships. The rationales shift with context but ultimately treat labor's embeddedness (Granovetter 1985) within the institutional practice of punishment as incompatible with the employment status associated with market exchange (Zatz 2008). This idea of a "separate world of the prison" (Vanskike v. Peters, 974 F.2d 810, 814 (7th Cir. 1992)) does not apply directly to those not incarcerated but instead at work "in the community." Indeed, the doctrine routinely attributes employment law protections to people who, while serving a carceral sentence, nonetheless are temporarily free on "work release," where they are treated as "free laborers in transition to their expected discharge from the prison" (Bennett v. Frank, 395 F.3d 409, 410 (7th Cir. 2005)). Little effort has been devoted, however, to mapping that boundary, and there is reason to doubt that it is firm (Zatz 2008).

In several contexts, labor protections already have been stripped from work outside incarceration but under carceral threat. The first involves the Thirteenth Amendment's bedrock prohibition of involuntary servitude. Because "involuntariness" generally applies to labor under threat of physical violence, whether private or public, work pursuant to carceral threat seemingly constitutes involuntary servitude under the constitutional analysis applied to criminal laws creating Jim Crow peonage, all the more so where debt creates the trilemma of pay, work, or jail (Zatz 2016). To be sure, complications arise from the Thirteenth Amendment's criminal punishment exception (Raghunath 2009), which some see as swallowing the rule (Childs 2015; but cf. Pope forthcoming). Child support enforcement, however, seemingly provides a clean case because the duty to work arises without any prior criminal conviction.

Nonetheless, courts have upheld incarceration of unemployed child support obligors against constitutional challenge. The limited case law relies on two lines of reasoning. The first finds no "servitude" so long as the work obligation is not specific to any one employer. In that sense, the worker is forced into the labor market where she remains free to choose (Zatz 2016; Pope 2010). The second argument, more relevant here, takes the opposite tack. In United States v. Ballek (170 F.3d 871 (9th Cir. 1999)), the Ninth Circuit explained that "not all forced employment is constitutionally prohibited" because obligations "traditionally ... enforced by means of imprisonment" are outside the constitutional prohibition (874). Judge Kozinski extended a set of late nineteenth- and early twentieth-century precedents that had upheld compulsory work by private sailors and conscription into military service or public road construction. Forced labor to generate child support vindicated a public duty "of vital importance to the community," not least because it offset the cost of public assistance. Thus, Ballek posits some purely "economic" sphere within which the Amendment ensures private economic freedom, but that freedom does not extend to work grounded in the principles organizing some other sphere. This simply generalizes the logic that renders penal servitude compatible with-because separate from — a "free labor system" in the market (Pope forthcoming). 
With regard to private sector employment, these rulings appear limited to Thirteenth Amendment protections. No court has stripped private employment of statutory protections by virtue of its mandatory character. However, both criminal legal debt and community supervision have generated specialized work programs, backed by carceral threat, that suggest how unprotected work could take root outside both the prison and the conventional labor market. As such, they suggest how "neoliberal paternalism" (Soss, Fording, and Schram 2011) or, relatedly, the "roll-out of marketmaking policies" (Grewal and Purdy 2015, 5) may not capture the full scope of work mandates; they do not invariably point toward marketized forms of work.

This dynamic is illustrated by court-ordered community service, which arises not only to "work off" criminal legal debt but also as an important noncarceral sanction generally (Tonry 1997). New York City judges extensively grant an "adjournment in contemplation of dismissal" (ACD) (Kohler-Hausmann 2018) conditioned on a misdemeanor defendant's performance of "services for a public or not-for-profit corporation, association, institution or agency” (N.Y. Crim. Proc. Law $§ 170.55(6)$ ). Although not technically linked to any financial obligation, one rationale for such work is that "[d]efendants who do not have money to make restitution should, when practical, pay for their offense through community service" (Doyle v. City of New York, 91 F. Supp.3d 480 (S.D.N.Y. 2015)).

A federal court recently rejected the first known employment law claim by ACD community service workers. They sought minimum wages under the Fair Labor Standards Act for collecting garbage and maintaining city parks and bridges. Relying on prison labor precedents, the court reasoned that these were not employment relationships because the work functioned not "to earn a living" but instead "to avoid further prosecution and the risk of conviction" and, in doing so, to discharge "a legal obligation to serve the public good" (Doyle, 488-89); note the echoes of Ballek on child support.

The Doyle workers received no direct economic benefit from their efforts, similar to "volunteers" generally excluded from employment law (Tsuruda 2018). This feature, however, may not prove limiting. Consider community service that "works off" criminal legal debt. Such workers never see a penny for their efforts, but they are credited with debt reductions in amounts based on a nominal hourly wage (Cal. Penal Code $\S$ 1209.5). In Los Angeles, debtors must sign a participation agreement declaring themselves to be "volunteers" "performing unpaid community service," "not an employee of the [agency]," and "not entitled to recover any workers' compensation benefits" in the event of injury (Zatz et al. 2016). Welfare agencies have similarly denied the employee status of workfare workers, though courts have sometimes disagreed (United States $v$. City of New York, 359 F.3d 83 (2d Cir. 2004); Goldberg 2007).

A further half-step beyond nominally unpaid "community service" lie the "transitional jobs programs" (TJPs) that currently are in vogue in reentry policy. These include both the CEO model discussed above and social entrepreneurship approaches like the well-known Homeboy Industries. The particular jobs, or the entire business, are created specifically to provide employment for disadvantaged workers and often incorporate supportive services. This facilitates integration of such programs into the job placement efforts of child support enforcement or community supervision. 
In the welfare-to-work context, TJPs were deliberately structured as wage-paying, legally protected employment in contrast to "workfare." Yet TJPs themselves are susceptible to efforts to structure and legally classify them in ways akin to classic "prison industries." Those often self-consciously mimic conventional businesses in their pay, supervision, and performance of "real work" making products for sale. Despite these features, courts have placed prison industries outside legal "employment" because the prison funnels workers into them and does so for "penological" or "rehabilitative" purposes (Zatz 2008). Thus, while the Doyle court repeatedly emphasized that ACD community service did not involve "work for the benefit of a private enterprise or ... produc[ing] goods or services that were sold in commerce" (ibid., 488) and implied that this feature was important to the result, such distinctions have not always held in prison labor jurisprudence.

Some recent developments suggest how work programs outside of prison could follow the prison industries model and allow Doyle to extend even to paid work yielding products for sale. For instance, Los Angeles' much-heralded \$15 local minimum wage included a partial carve-out for transitional employers such as Homeboy (Reyes 2015). Similarly, in the Oklahoma poultry processing scheme mentioned above (A. J. Harris and Walter 2017), "drug court" defendants were forced to work the poultry processing line of major commercial firms and perform work functionally indistinguishable from regular employees. These work assignments, however, were structured through an intermediary, Christian Alcoholics \& Addicts in Recovery (CAAIR), which purportedly provided residential drug rehabilitation services. Like a temp agency, CAAIR was paid by the poultry processor, but CAAIR pocketed the entire wage to fund its operation. Technically, the court ordered the defendants into rehab on CAAIR's terms. CAAIR required them to sign waivers declaring themselves to be "clients," not "employees," much as the Los Angeles community service intermediaries do.

These examples suggest how Doyle and Ballek might be generalized. By segregating work from "regular" employees, employing alternative currencies of debt relief (Zelizer 1997), and assigning and monitoring participation through specialized institutions, such work structures might do sufficient "relational work" (Zelizer 2005; Zatz 2008) for courts or legislatures to place them outside conventional employment law. In that position, the downward pressures identified in the previous subsections could operate without any restraining floor and could create a legally second-class tier of work available to public agencies and private firms alike.

\section{Disciplining and Displacing Other Workers}

Even workers not personally subject to carceral work mandates may feel their effects. As Angela Davis recounts, "DuBois made the astute observation that so-called 'free' black labor was, in a very concrete sense, chained to black convict labor" $(1999,356)$. The availability of one vulnerable labor force tends to discipline the demands of others. The latter fears displacement by the former. Harris \& Walter's reporting on CAAIR (2017), for instance, notes how a chicken processor was laying off paid employees while becoming increasingly reliant on workers subject to carceral work mandates. 
Such discipline and displacement is a familiar issue in public benefits, immigrant labor, and prison labor contexts. Consider the "prevailing conditions" rule in unemployment insurance (Kilbane 1998). If a job offers terms below what prevails for that occupation in the local labor market, an unemployed person may refuse it without jeopardizing their benefits, even if the job is otherwise suitable. This limits downward pressure on labor standards from a pool of unemployed job seekers. Similar principles underlie wage regulation in agricultural guestwork and commercial prison labor programs (J. J. Lee 2017; Zatz 2008). So, too, with the standard "competitive fairness" rationale (S. D. Harris 2000) for applying employment laws to stigmatized workers such as unauthorized immigrants (Motomura 2010), welfare recipients, and prison inmates (Zatz 2008): directly protecting one group of workers also indirectly protects others (and the firms hiring them) with whom they compete. Similar concerns apply to how employers could use carceral threats to disrupt worker collective action. Employer-triggered immigration enforcement, for instance, not only provides retaliatory leverage against individual workers but also may undermine organizing that crosses immigration status lines and could benefit authorized workers.

Efforts to equalize labor standards across work status can limit employer incentives to utilize vulnerable workforces to lower costs or expand control. A more direct approach bars employing such workforces unless "regular" workers are unavailable and thus not at risk of displacement. Such anti-displacement provisions are common in welfare work programs (Dietrich, Emsellem, and Yau 1996-1997) and agricultural guestwork (J. J. Lee 2017), and similar principles have steered prison labor expansion toward industries that otherwise would move production abroad (Weiss 2001).

Rather than limiting, or upgrading, precarious work, however, the competitive fairness rationale can simply concentrate unprotected or vulnerable workers in jobs that seem not to threaten "regular" workers. One crude example is rules limiting prison labor or welfare work assignments to governmental or non-profit enterprises (McLennan 2008) or to enterprises that do not produce goods or services for sale. Recall how a similar principle animated Doyle's denial of employee status to New York's ACD community service workers. In this fashion, anti-displacement concerns may actually amplify the dynamics that create separate, second-class workforces.

\section{CONCLUSIONS}

Today's carceral state operates as a labor market institution in an especially robust sense. Rather than simply removing people from the labor market or blocking access to it, carceral work mandates do the seeming opposite: forcefully inserting people into work, governing the conditions of their labor, and doing so in the ostensibly free world of regular work, not solely the segmented world of prison. This form of subordinated inclusion sheds new light on the nature and origins of precarious work under neoliberalism, complementing accounts of regulatory withdrawal and centering the institutions of state violence most closely associated with contemporary racial hierarchy. It provides a context in which to answer Michael Dawson's call to "better understand the relationship between the attacks on black bodies and continued systemic economic subordination of black communities" (2016, 157). 
There remains much to learn about these carceral work mandates. This includes basic questions about scale-both in absolute terms but especially in relation to the lowwage labor force-and about variability, within and across jurisdictions and over time. Also, how do key actors-judges, administrative agency staff, probation officers, job services programs, employers, and so on-exercise discretion, breathe practical meaning into concepts of "willfulness" or "involuntariness," and interact with each other? How, too, do people subjected to these mandates navigate or resist them, understand their lives in relation to and through them-as workers? As criminal defendants? As parents? As debtors? As racialized and gendered subjects? (cf. Reese and Newcombe 2003). How is this connected to or dissociated from other experiences of work and unemployment, of the criminal legal system, and/or of racial and economic inequality, including how racialization varies across both groups and institutional contexts? And what effects, if any, can be discerned with regard to time spent at work, in what sorts of jobs, and under what conditions?

Such questions can be asked about specific sources of carceral work mandateschild support enforcement, criminal legal debt, community supervision-and also in more aggregated or intersecting fashion (Haney 2018). How many people experience multiple forms of carceral work mandates, either at once or in succession? And how do these interact not only among themselves but also with closely related institutions such as welfare work requirements, prison labor, and immigration enforcement, as well as street policing (Stuart 2011) and debt collection? Finally, how do carceral work mandates relate to the more familiar processes of labor market exclusion and deregulation? Do they work at cross purposes to create "double binds" (Augustine 2019) and offsetting effects, or in more complementary or synthetic fashion ${ }^{37}$

Asking such questions can enhance understanding of contemporary political economy, including basic categories_-and their embedded analyses-such as the carceral state or neoliberalism. Particularly significant is the integration of carceral state power into the machinery of labor markets. This provides an opportunity to explore-and to link-both how racial power may be constitutive of contemporary political economy and how analyzing neoliberalism as marketization risks mystifying the sociolegal constitution of markets themselves (Edelman 2004).

In his magnum opus Black Marxism, Cedric Robinson ([1983] 2000) theorizes "racial capitalism" in substantial part by emphasizing the persistent integration into capitalist development of slavery and other forms of thoroughly racialized labor coercion, both domestically and transnationally (cf. Blackett 2011; Hall 1980). This runs counter to the orthodox Marxian notion of "free" wage labor as the fundamental capitalist mode of production, leaving slavery and other forced labor, including prison labor (Melossi 2003), as vestigial "primitive accumulation." In this vein, carceral work mandates offer a site that extends into the present the insights of historiography of slavery and neoslavery-including chain gangs and convict leasing - as integral to US racial capitalism (Baptist 2014; Haley 2016; Lichtenstein 1996).

Crucially, however, and unlike looking strictly to modern prison labor as the successor to these forms, carceral work mandates do not operate in even a notionally

17. Complementarity may arise when, as is often the case, exclusion and mandates apply to different jobs, working together to funnel people into the bottom extremes of the labor market (Zatz forthcoming). 
separate mode of production apart from wage labor (cf. Hall 1980, 339-40). Instead, the racialized power of the criminal legal system structures the terms of entry into and exit from wage labor. Moreover, it helps set the terms and conditions of work that ordinarily are conceptualized as the outcome of market bargaining. Nor, in such moments, should the racial structuring of work be conceptualized as some kind of import or intrusion into the labor market from the outside sphere of criminal law (Ho 2018; Appel 2019). That is most obvious when racialized accounts of work effort, skill, and discipline, as well as of needs for income, time with family, and so on, themselves become inputs into the operation of carceral work mandates. More generally, this illustrates the insight from economic sociology and anthropology that market interactions always are socially embedded and constituted (Polanyi [1944] 2001; Granovetter 1985; Krippner and Alvarez 2007).

Finally, it bears noting that, while my emphasis has been on the carceral regulation of labor, the direction of analysis might readily be reversed. Immigration scholars, for instance, have conceptualized both individual employers and the labor market generally as immigration screeners or sorters (S. Lee 2009). Similarly, employers might be understood to act as extensions of the criminal legal system, with carceral work mandates rendering outcomes at work (including unemployment) a basis for subjection to or avoidance of state violence (Simon 1993; Kohler-Hausman 2018; Levin 2018). ${ }^{18}$ Informed by my main argument here, however, such an analysis would have to avoid treating "the labor market" as generating outcomes independent of and prior to subjection to carceral institutions. In this fashion, studying carceral work mandates may provide an opportunity for synthesis that engages what Gilmore has characterized as a "triple-pronged attack on working people" with its mirror-image "potential for identifying linkages between immigrant, labor, and antiprison activism" (2007, 246).

\section{REFERENCES}

Alexander, Michelle. The New Jim Crow: Mass Incarceration in the Age of Colorblindness. New York: The New Press, 2012.

American Civil Liberties Union. "Ending Modern-Day Debtors' Prisons.” 2018. https://www.aclu.org/ issues/criminal-law-reform/ending-modern-day-debtors-prisons.

Appel, Hannah. The Licit Life of Capitalism: US Oil in Equatorial Guinea. Durham, NC: Duke University Press, 2019.

Arup, Christopher, Peter Gahan, John Howe, Richard Johnstone, Richard Mitchell, and Anthony O'Donnell, eds. Labour Law and Labour Market Regulation: Essays on the Construction, Constitution and Regulation of Labour Markets and Work Relationships. Sydney: Federation Press, 2006.

Atkinson, Abbye. "Consumer Bankruptcy, Nondischargeability, and Penal Debt." Vanderbilt Law Review, 70, no. 3 (2017): 917-83.

Augustine, Dallas. "Working Around the Law: Navigating Legal Barriers to Good Work During Reentry." Law E⿱ Social Inquiry 44, no. 3 (2019): 726-51.

Bannon, Alicia, Mitali Nagrecha, and Rebekah Diller. Criminal Justice Debt: A Barrier to Reentry. Brennan Center for Justice, 2010.

18. Hatton suggests something similar in her conceptualization of workfare and prison labor as effectuating "work as punishment" (2018b). 
Baptist, Edward. The Half Has Never Been Told: Slavery and the Making of American Capitalism. New York: Basic Books, 2014.

Barker, Vanessa. Imprisonment and the Democratic Process. New York: Oxford University Press, 2009.

Beckett, Katherine, and Naomi Murakawa. "Mapping the Shadow Carceral State: Toward an Institutionally Capacious Approach to Punishment." Theoretical Criminology 16, no. 2 (2012): 221-44.

Beckwith, Ruthie-Marie. Disability Servitude: From Peonage to Poverty. New York: Palgrave Macmillan, 2016.

Berlin, Gordon L. What Works in Welfare Reform. Manpower Demonstration Research Corporation, 2002.

Bernhardt, Annette, Heather Boushey, Laura Dresser, and Chris Tilly. "An Introduction to the 'Gloves-Off Economy." In The Gloves-Off Economy: Workplace Standards at the Bottom of America's Labor Market. Edited by Annette Bernhardt, Heather Boushey, Laura Dresser, and Chris Tilly, 1-22. Ithaca, NY: Cornell University Press, 2008.

Bernhardt, Annette, Michael W. Spiller, and Diana Polson. "All Work and No Pay: Violations of Employment and Labor Laws in Chicago, Los Angeles and New York City." Social Forces 91, no. 3 (2013): 725-46.

Bingham, Stephen, Mari Castaldi, Elisa Della-Piana, Meredith Desautels, Antoinette Dozier, Kristina Harootun, Michael Herald, et al. Stopped, Fined, Arrested: Racial Bias in Policing and Traffic Courts in California. Lawyers' Committee for Civil Rights of the San Francisco Bay Area, 2016.

Birckhead, Tamar R. "The New Peonage." Washington and Lee Law Review 72, no. 4 (2015): 1595-678.

Blackett, Adelle. "Emancipation in the Idea of Labour Law." In The Idea of Labour Law. Edited by Brian Langille and Guy Davidov, 420-36. New York: Oxford University Press, 2011.

Blackmon, Douglas A. Slavery By Another Name: The Re-Enslavement of Black Americans from the Civil War to World War II. New York: Anchor Books, 2008.

Bonds, Michael. "The Continuing Significance of Race: A Case Study of the Impact of Welfare Reform." Journal of African American Studies 9, no. 4 (2006): 18-31.

Brinig, Margaret F., and Marsha Garrison. "Getting Blood From Stones: Results and Policy Implications of an Empirical Investigation of Child Support Practice in St. Joseph County, Indiana Paternity Actions." Family Court Review 56, no. 4 (2018): 521-43. doi:10.1111/fcre.12365.

Brito, Tonya. "Fathers Behind Bars: Rethinking Child Support Policy Toward Low-Income Fathers and Their Families." Journal of Gender, Race E Justice 15, no. 3 (2012): 617-73.

Brito, Tonya L., David J. Jr. Pate, and Jia-Hui Stafanie Wong. "I Do for My Kids: Negotiating Race and Racial Inequality in Family Court." Fordham Law Review 83 (2015): 3027-52.

Broadus, Joseph, Sara Muller-Ravett, Arielle Sherman, and Cindy Redcross. A Successful Prisoner Reentry Program Expands: Lessons from the Replication of the Center for Employment Opportunities. MDRC, 2016.

Brodkin, Evelyn Z. "Inside the Welfare Contract: Discretion and Accountability in State Welfare Administration." Social Service Review 71, no. 1 (1997): 1-33.

Bumiller, Kristin. "Incarceration, Welfare State and Labour Market Nexus The Increasing Significance of Gender in the Prison System." In Women Exiting Prison. Edited by Bree Carlton and Marie Segrave, 13-34. New York: Routledge, 2013.

. "Bad Jobs and Good Workers: The Hiring of Ex-Prisoners in a Segmented Economy." Theoretical Criminology 19, no. 3 (2015): 336-54.

Cammett, Ann. "Deadbeats, Deadbrokes, and Prisoners." Georgetown Journal on Poverty Law $\mathcal{E}$ Policy 18, no. 2 (2011): 127-68.

Cancian, Maria, Carolyn J. Heinrich, and Yiyoon Chung. "Discouraging Disadvantaged Fathers' Employment: An Unintended Consequence of Policies Designed to Support Families." Journal of Policy Analysis and Management 32, no. 4 (2013): 758-84.

Cancian, Maria, Robert H. Haveman, Daniel R. Meyer, and Barbara Wolfe. "Before and After TANF: The Economic Well-Being of Women Leaving Welfare." Social Service Review 76, no. 4 (2002): $603-41$.

Carbado, Devon, Catherine Fisk, and Mitu Gulati. "After Inclusion.” Annual Review of Law $\mathcal{E}$ Social Science 4 (2008): 83-102. 
Childs, Dennis. Slaves of the State: Black Incarceration from the Chain Gang to the Penitentiary. Minneapolis, MN: University of Minnesota Press, 2015.

Chung, Yiyoon. "Child Support as Labor Regulation." Journal of Sociology $\mathcal{G}$ Social Welfare 38, no. 3 (2011): 73-99.

Civil Rights Division, U.S. Department of Justice. Investigation of the Ferguson Police Department. 2015.

Colgan, Beth A. "Reviving the Excessive Fines Clause." California Law Review 102, no. 2 (2014): $277-350$.

_. "Graduating Economic Sanctions According to Ability to Pay." Iowa Law Review 103 (2017): 53-112.

Cozzolino, Elizabeth. "Public Assistance, Relationship Context, and Jail for Child Support Debt." Socius 4 (2018).

Daniel, Pete. The Shadow of Slavery: Peonage in the South, 1901-1969. Chicago: University of Illinois Press, 1972.

Davis, Angela Y. "From the Prison of Slavery to the Slavery of Prison: Frederick Douglass and the Convict Lease System." In Frederick Douglass: A Critical Reader. Edited by Bill E. Lawson and Frank M. Kirkland, 339-62. Malden, MA: Blackwell, 1999.

- "From the Convict Lease System to the Super-Max Prison." In States of Confinement. Edited by Joy James, 60-74. New York: St. Martin's Press, 2000.

Dawson, Michael C. "Hidden in Plain Sight: A Note on Legitimation Crises and the Racial Order." Critical Historical Studies 3, no. 1 (2016): 143-61.

De Genova, Nicholas. Working the Boundaries: Race, Space, and "Illegality" in Mexican Chicago. Durham, NC: Duke University Press, 2005.

Dietrich, Sharon, Maurice Emsellem, and Karen Kithan Yau. "Welfare Reforming the Workplace: Protecting the Employment Rights of Welfare Recipients, Immigrants, and Displaced Workers." Clearinghouse Review 30 (1996-1997): 903-31.

Diller, Matthew. "Entitlement and Exclusion: The Role of Disability in the Social Welfare System." UCLA Law Review 44, no. 2 (1996): 361-465.

Doherty, Fiona. "Obey All Laws and Be Good: Probation and the Meaning of Recidivism." Georgetown Law Journal 104, no. 2 (2015): 291-354.

Edelman, Lauren B. "Rivers of Law and Contested Terrain: A Law and Society Approach to Economic Rationality." Law $\mathcal{E}$ Society Review 38, no. 2 (2004): 181-98.

Equal Justice Under Law. "Shutting Down Debtors' Prisons." 2018. https://equaljusticeunderlaw.org/ private-debtors-prisons.

Fineman, Martha Albertson. The Neutered Mother, the Sexual Family, and Other Twentieth Century Tragedies. New York: Routledge, 1995.

Gans, Herbert J. "Positive Functions of the Undeserving Poor: Uses of the Underclass in America." Politics $\mathcal{E}$ Society 22, no. 3 (1994): 269-83.

Gardner, Josh, and Reuters. "Marchers Get Racist Reception in Rural Missouri Town." Daily Mail, December 5, 2014. http://www.dailymail.co.uk/news/article-2861693/120-mile-Ferguson-marchmet-display-melon-fried-chicken-40oz-beer-racist-counter-protesters-rural-Missouri.html.

Gilmore, Ruth Wilson. Golden Gulag: Prisons, Surplus, Crisis, and Opposition in Globalizing California. Berkeley, CA: University of California Press, 2007.

"What Is To Be Done? (Presidential Address)." American Quarterly 63, no. 2 (2011): 245-65.

Glenn, Evelyn Nakano. Unequal Freedom: How Race and Gender Shaped American Citizenship and Labor. Cambridge, MA: Harvard University Press, 2002.

Goldberg, Chad Alan. Citizens and Paupers: Relief, Rights, and Race from the Freedmen's Bureau to Workfare. Chicago: University of Chicago Press, 2007.

Goluboff, Risa L. The Lost Promise of Civil Rights. Cambridge, MA: Harvard University Press, 2007.

Gordon, Jennifer. "Transnational Labor Citizenship." Southern California Law Review 80, no. 3 (2006): 503-88.

Gordon, Jennifer, and Robin A. Lenhardt. "Rethinking Work and Citizenship." UCLA Law Review 55, no. 5 (2007): 1161-238.

Granovetter Mark. "Economic Action and Social Structure: The Problem of Embeddedness." American Journal of Sociology 91, no. 3 (1985): 481-510. 
Grewal, David, and Jedediah Purdy. "Law and Neoliberalism." Law and Contemporary Problems 77, no. 4 (2015): 1-23.

Gurusami, Susila. "Working for Redemption: Formerly Incarcerated Black Women and Punishment in the Labor Market." Gender Eु Society 31, no. 4 (2017): 433-56.

Gustafson, Kaaryn. Cheating Welfare: Public Assistance and the Criminalization of Poverty. New York: NYU Press, 2011.

—. "Degradation Ceremonies and the Criminalization of Low-Income Women." U.C. Irvine Law Review 3 (2013): 297-358.

Haley, Sarah. No Mercy Here: Gender, Punishment, and the Making of Jim Crow Modernity. Chapel Hill, NC: University of North Carolina Press, 2016.

Hall, Stuart. "Race, Articulation and Societies Structured in Dominance." In Sociological Theories: Race and Colonialism, 305-45. Paris: UNESCO, 1980.

Hampson, Christopher. "State Bans on Debtors' Prisons and Criminal Justice Debt." Harvard Law Review 129, no. 4 (2016): 1024-45.

Handler, Joel F. Social Citizenship and Workfare in the United States and Western Europe: The Paradox of Inclusion. New York: Cambridge University Press, 2004.

Handler, Joel F., and Yeheskel Hasenfeld. The Moral Construction of Poverty. Newbury Park, CA: Sage, 1991.

Haney, Lynne. "Incarcerated Fatherhood: The Entanglements of Child Support Debt and Mass Imprisonment." American Journal of Sociology 124, no. 1 (2018): 1-48.

Hannah-Moffat, Kelly, and Paula Maurutto. "Shifting and Targeted Forms of Penal Governance: Bail, Punishment and Specialized Courts." Theoretical Criminology 16, no. 2 (2012): 201-19.

Harcourt, Bernard E. The Illusion of Free Markets: Punishment and the Myth of Natural Order. Cambridge, MA: Harvard University Press, 2011.

Haney López, Ian. Dog Whistle Politics: How Coded Racial Appeals Have Reinvented Racism and Wrecked the Middle Class, New York: Oxford University Press, 2013.

Harris, Alexes. A Pound of Flesh: Monetary Sanctions as Punishment for the Poor. New York: Russell Sage Foundation, 2016.

Harris, Alexes, Heather Evans, and Katherine Beckett. "Drawing Blood from Stones: Legal Debt and Social Inequality in the Contemporary United States." American Journal of Sociology 115, no. 6 (2010): 1753-99.

Harris, Amy Julia, and Shoshana Walter. "All Work. No Pay: They Thought They Were Going to Rehab. They Ended up in Chicken Plants." Reveal, October 4, 2017. https://www.revealnews.org/ article/they-thought-they-were-going-to-rehab-they-ended-up-in-chicken-plants.

Harris, Seth D. "Conceptions of Fairness in the Fair Labor Standards Act." Hofstra Labor \& Employment Law Journal 18, no. 1 (2000): 19-166.

Hatcher, Daniel L. "Child Support Harming Children: Subordinating the Best Interests of Children to the Fiscal Interests of the State." Wake Forest Law Review 42, no. 4 (2007): 1029-86.

Hatton, Erin. "Work beyond the Bounds: A Boundary Analysis of the Fragmentation of Work." Work, Employment and Society 29, no. 6 (2015): 1007-18.

. "Either You Do It or You're Going to the Box': Coerced Labor in Contemporary America." Critical Sociology, April 2018a.

"When Work Is Punishment: Penal Subjectivities in Punitive Labor Regimes." Punishment $\mathbb{E}$ Society 20, no. 2 (2018b): 174-91.

Hays, Sharon. Flat Broke With Children: Women in the Age of Welfare Reform. New York: Oxford University Press, 2003.

Hernández, Kelly Lytle, Khalil Gibran Muhammad, and Heather Ann Thompson. "Introduction: Constructing the Carceral State." Journal of American History 102, no. 1 (2015): 18-24.

Ho, Karen. "Markets, Myths, and Misrecognitions: Economic Populism in the Age of Financialization and Hyperinequality." Economic Anthropology 5, no. 1 (2018):148-50.

Holland, Gale. "Court Improperly Suspends Poor People's Driver Licenses, Suit Alleges." Los Angeles Times, August 2, 2016.

Holzer, Harry J., Paul Offner, and Elaine Sorensen. "Declining Employment Among Young Black Less-Educated Men: The Role of Incarceration and Child Support." Journal of Policy Analysis and Management 24, no. 2 (2005): 329-50. 
Johnson, Mark-Anthony, Rachel Herzing, Mary Hooks, and Marbre Stahly-Butts. "An End To Money Bail, Mandatory Fines, Fees, Court Surcharges, and 'Defendant Funded' Court Proceedings." In A Vision For Black Lives. Edited by Movement for Black Lives, 2016.

Kaeble, Danielle, Laura M. Maruschak, and Thomas P. Bonczar. Probation and Parole in the United States, 2014. Bureau of Justice Statistics, U.S. Department of Justice, 2015.

Kalleberg, Arne L. Good Jobs, Bad Jobs: The Rise of Polarized and Precarious Employment Systems in the United States, 1970s-2000s. New York: Russell Sage Foundation, 2011.

Kelley, Robin D. G. Hammer and Hoe: Alabama Communists During the Great Depression. 25th anniversary edition. Chapel Hill, NC: University of North Carolina Press, 2015.

Kelman, Mark. "Market Discrimination and Groups." Stanford Law Review 53, no. 4 (2001): 833-96.

Kilbane, Grace A. Application of the Prevailing Conditions of Work Requirement. Unemployment Insurance Program Letter 41-98. U.S. Department of Labor, 1998.

Kim, Kathleen. "Beyond Coercion." UCLA Law Review 62 (2015): 1558-84.

Kohler-Hausmann, Issa. Misdemeanorland: Criminal Courts and Social Control in an Age of Broken Windows Policing. Princeton, NJ: Princeton University Press, 2018.

Krippner, Greta R., and Anthony S. Alvarez. "Embeddedness and the Intellectual Projects of Economic Sociology.” Annual Review of Sociology 33 (2007): 219-40.

Lafer, Gordon. The Job Training Charade. Ithaca, NY: Cornell University Press, 2004.

Lamont, Michèle. The Dignity of Working Men: Morality and the Boundaries of Race, Class, and Immigration. New York: Russell Sage Foundation, 2000.

Lee, Jennifer J. "U.S. Workers Need Not Apply: Challenging Low-Wage Guest Worker Programs." Stanford Law EB Policy Review 28, no. 1 (2017): 1-60.

Lee, Stephen. "Private Immigration Screening in the Workplace." Stanford Law Review 61, no. 5 (2009): 1103-45.

Levin, Benjamin. "Criminal Employment Law." Cardozo Law Review 39, no. 6 (2018): 2265-328.

Lichtenstein, Alex. Twice the Work of Free Labor: The Political Economy of Convict Labor in the New South. New York: Verso, 1996.

Lipsky, Michael. Street-Level Bureaucracy: Dilemmas of the Individual in Public Services. New York: Russell Sage Foundation, 1980.

Loeffler, Charles E. "Does Imprisonment Alter the Life Course? Evidence on Crime and Employment from a Natural Experiment." Criminology 51, no. 1 (2013): 137-66.

Lynch, Mona. "Theorizing the Role of the 'War on Drugs' in US Punishment." Theoretical Criminology 16, no. 2 (2012): 175-99.

Marshall, T. H. "Citizenship and Social Class." In Citizenship and Social Class and Other Essays. By T.H. Marshall, 1-85. Cambridge, UK: Cambridge University Press, 1950.

Massey, Douglas S., and Kerstin Gentsch. "Undocumented Migration to the United States and the Wages of Mexican Immigrants." International Migration Review 48, no. 2 (2014): 482-99.

McLennan, Rebecca M. The Crisis of Imprisonment: Protest, Politics, and the Making of the American Penal State, 1776-1941. New York: Cambridge University Press, 2008.

Mead, Lawrence M. "Why We Need Work Programs for Fathers." Journal of Policy Analysis and Management 29, no. 3 (2010): 610-16.

— Expanding Work Programs for Poor Men. Washington, D.C.: AEI Press, 2011.

Melossi, Dario. "Introduction." In Punishment and Social Structure. By Georg Rusche and Otto Kirchheimer. New Brunswick, NJ: Transaction Publishers, 2003.

Miller, Daniel P., and Ronald B. Mincy. "Falling Further Behind? Child Support Arrears and Fathers' Labor Force Participation." Social Service Review 86, no. 4 (2012): 604-35.

Mississippi Department of Corrections. "Restitution Centers." Accessed 14 February 2019. https:// www.mdoc.ms.gov/Community-Corrections/Pages/Restitution-Centers.aspx.

Motomura, Hiroshi. "The Rights of Others: Legal Claims and Immigration Outside the Law." Duke Law Journal 59 (2010): 1723-86.

Murch, Donna. "Paying for Punishment: The New Debtors' Prison." Boston Review, August 1, 2016.

Natapoff, Alexandra. "Misdemeanor Decriminalization." Vanderbilt Law Review 68, no. 4 (2015): 1055-116. 
National Research Council. The Growth of Incarceration in the United States: Exploring Causes and Consequences. Washington, DC: National Academies Press, 2014.

National Council of State Legislatures. Criminal Nonsupport and Child Support. 2015. http://www.ncsl. org/research/human-services/child-support-homepage.aspx

Nicholson, Walter, and Karen Needels. "Unemployment Insurance: Strengthening the Relationship between Theory and Policy." Journal of Economic Perspectives 20, no. 3 (2006): 47-70.

Nolan, James. "Therapeutic Adjudication." Society 39, no. 2 (2002): 29-38.

Office of Child Support Enforcement, U.S. Department of Health and Human Services. "Flexibility, Efficiency, and Modernization in Child Support Enforcement Programs." Notice of Proposed Rulemaking. Federal Register, 79 (2014): 68547-87.

. Preliminary Report: FY 2015. 2016.

Omi, Michael, and Howard Winant. Racial Formation in the United States. 3rd ed. New York: Routledge, 2015.

Ontiveros, Maria L. "Noncitizen Immigrant Labor and the Thirteenth Amendment: Challenging Guest Worker Programs." University of Toledo Law Review 38, no. 3 (2006): 923.

Page, Joshua, and Joe Soss. "Criminal Justice Predation and Neoliberal Governance." In Rethinking Neoliberalism: Resisting the Disciplinary Regime. Edited by Sanford F. Schram and Marianna Pavlovskaya, 139-59. New York: Routledge, 2017.

Pager, Devah. Marked: Race, Crime, and Finding Work in an Era of Mass Incarceration. Chicago: University of Chicago Press, 2008.

Pager, Devah, Bruce Western, and Naomi Sugie. "Sequencing Disadvantage: Barriers to Employment Facing Young Black and White Men with Criminal Records." The ANNALS of the American Academy of Political and Social Science 623, no. 1 (2009): 195-213.

Patterson, Elizabeth G. "Civil Contempt and the Indigent Child Support Obligor: The Silent Return of Debtor's Prison." Cornell Journal of Law Eु Public Policy 18, no. 1 (2008): 95-141.

Peck, Jamie, and Nik Theodore. "Carceral Chicago: Making the Ex-Offender Employability Crisis." International Journal of Urban and Regional Research 32, no. 2 (2008): 251-81.

Petersilia, Joan. When Prisoners Come Home: Parole and Prisoner Reentry. New York: Oxford University Press, 2003.

Pettit, Becky, and Christopher Lyons. "Status and the Stigma of Incarceration: The Labor Market Effects of Incarceration by Race, Class, and Criminal Involvement." In Barriers to Reentry? Edited by Shawn D. Bushway, David F. Weiman, and Michael A. Stoll, 203-26. New York: Russell Sage Foundation, 2007.

Pfaff, John F. Locked In: The True Causes of Mass Incarceration and How to Achieve Real Reform. New York: Basic Books, 2017.

Phelps, Michelle S. "Mass Probation and Inequality: Race, Class, and Gender Disparities in Supervision and Revocation." In Handbook on Punishment Decisions. Edited by Jeffery T. Ulmer and Mindy S. Bradley, 43-65. New York: Routledge, 2018.

Piven, Frances Fox, and Richard A. Cloward. Regulating the Poor: The Functions of Public Welfare. 2nd ed. New York: Vintage Books, 1993.

Polanyi, Karl. The Great Transformation: The Political and Economic Origins of Our Time. Boston: Beacon Press, (1944) 2001.

Pope, James Gray. "Contract, Race, and Freedom of Labor in the Constitutional Law of 'Involuntary Servitude." Yale Law Journal 119 (2010): 1474-567.

- "Mass Incarceration, Convict Leasing, and the Original Meanings of the Thirteenth Amendment's Punishment Clause." New York University Law Review 94 (forthcoming).

Raghunath, Raja. "A Promise the Nation Cannot Keep: What Prevents the Application of the Thirteenth Amendment in Prison." William and Mary Bill of Rights Journal 18, no. 2 (2009): 395-444.

Redcross, Cindy, Megan Millenky, Timothy Rudd, and Valerie Levshin. More than a Job: Final Results from the Evaluation of the Center for Employment Opportunities (CEO) Transitional Jobs Program. OPRE Report 2011-18. U.S. Department of Health and Human Services, 2012.

Reese, Ellen, and Garnett Newcombe. "Income Rights, Mothers' Rights, or Workers' Rights? Collective Action Frames, Organizational Ideologies, and the American Welfare Rights Movement." Social Problems 50, no. 2 (2003): 294-318. 
Reichman, Nancy E., Julien O. Teitler, Irwin Garfinkel, and Sara S. McLanahan. "Fragile Families: Sample and Design." Children and Youth Services Review 23, no. 4 (2001): 303-26.

Reyes, Emily A. "L.A. Nonprofits Aiding Hard-to-Employ May Get Temporary Wage Hike Exemption." Los Angeles Times, June 23, 2015.

Roberts, Dorothy E. "The Value of Black Mothers' Work." Connecticut Law Review 26, no. 3 (1994): 871-78.

_ "Prison, Foster Care, and the Systemic Punishment of Black Mothers." UCLA Law Review 59 (2012): 1474-501.

Robinson, Cedric J. Black Marxism: The Making of the Black Radical Tradition. Chapel Hill, NC: University of North Carolina Press, (1983) 2000.

Robles, Frances, and Shaila Dewan. "Skip Child Support. Go to Jail. Lose Job. Repeat." New York Times, April 20, 2015.

Rossman, Shelli B., John Roman, Janine M. Zweig, Michael Rempel, and Christine Lindquist. The Multi-Site Adult Drug Court Evaluation: The Impact of Drug Courts. Vol. 4. Urban Institute, 2011.

Rusche, Georg, and Otto Kirchheimer. Punishment and Social Structure. New Brunswick, NJ: Transaction Publishers, (1939) 2003.

Schroeder, Daniel, and Nicholas Doughty. Texas Non-Custodial Parent Choices: Program Impact Analysis. Ray Marshall Center, University of Texas at Austin, 2009.

Seamster, Louise, and Raphaël Charron-Chénier. "Predatory Inclusion and Education Debt: Rethinking the Racial Wealth Gap." Social Currents 4, no. 3 (2017): 199-207.

Simon, Jonathan. Poor Discipline: Parole and the Social Control of the Underclass, 1890-1990. Chicago: University of Chicago Press, 1993.

- Governing Through Crime: How the War on Crime Transformed American Democracy and Created a Culture of Fear. New York: Oxford University Press, 2007.

_. "Law's Violence, the Strong State, and the Crisis of Mass Imprisonment (for Stuart Hall)." Wake Forest Law Review 49 (2014): 649-76.

Smith, Earl, and Angela J. Hattery. "Incarceration: A Tool for Racial Segregation and Labor Exploitation." Race, Gender $\mathcal{E}$ Class 15, nos. 1/2 (2008): 79-97.

Smith, Rebecca, Ana Avendaño, and Julie Martínez Ortega. ICEd Out: How Immigration Enforcement Has Interfered with Workers' Rights. National Employment Law Project, 2009.

Sorensen, Elaine. "Rethinking Public Policy Toward Low-Income Fathers in the Child Support Program." Journal of Policy Analysis and Management 29, no. 3 (2010): 604-10.

Sorensen, Elaine, and Chava Zibman. "Getting to Know Poor Fathers Who Do Not Pay Child Support." Social Service Review 75, no. 3 (2001): 420-34.

Sorensen, Elaine, Liliana Sousa, and Simon Schaner. Assessing Child Support Arrears in Nine Large States and the Nation. Urban Institute, 2007.

Soss, Joe, Richard C. Fording, and Sanford Schram. Disciplining the Poor: Neoliberal Paternalism and the Persistent Power of Race. Chicago: University of Chicago Press, 2011.

Steinberg, Robin, and David Feige. "The Problem with NYC's Bail Reform." The Marshall Project, July 9, 2015. https://www.themarshallproject.org/2015/07/09/the-problem-with-nyc-s-bail-reform.

Stuart, Forrest. "Race, Space, and the Regulation of Surplus Labor: Policing African Americans in Los Angeles's Skid Row." Souls: A Critical Journal of Black Politics, Culture, and Society 13, no. 2 (2011): 197-212.

Sugie, Naomi F. "Work as Foraging: A Smartphone Study of Job Search and Employment after Prison." American Journal of Sociology 123, no. 5 (2018): 1453-91.

Sunstein, Cass R. "Lochner's Legacy." Columbia Law Review 87, no. 5 (1987): 873-919.

Temporary State Commission on Management and Productivity in the Public Sector. The Restitution Center Concept as a Part of the Criminal Justice System. New York (1977).

Thompson, Heather Ann. "Rethinking Working-Class Struggle through the Lens of the Carceral State: Toward a Labor History of Inmates and Guards." Labor: Studies in Working Class History of the Americas 8, no. 3 (2011): 15-45.

Tomlins, Christopher. "Subordination, Authority, Law: Subjects in Labor History." International Labor Eु Working Class History 47 (1995): 56-90. 
Tonry, Michael. "Evaluating Intermediate Sanction Programs." In Community Corrections. Edited by Joan Petersilia, 79-96. New York: Oxford University Press, 1997).

Travis, Jeremy. But They All Come Back: Facing the Challenges of Prisoner Reentry. Washington, DC: Urban Institute Press, 2005.

Travis, Lawrence F., and James Stacey. "A Half Century of Parole Rules: Conditions of Parole in the United States, 2008." Journal of Criminal Justice 38, no. 4 (2010): 604-08.

Tsuruda, Sabine. "Volunteer Work, Inclusivity, and Social Equality." In The Philosophical Foundations of Labour Law. Edited by Hugh Collins, Gillian Lester, and Virginia Mantouvalou, 306-21. Oxford: Oxford University Press, 2018.

Turetsky, Vicki. Alternatives to Incarceration. Information Memorandum IM-12-01. Office of Child Support Enforcement, U.S. Department of Health and Human Services, 2012.

VanderVelde, Lea S. "The Labor Vision of the Thirteenth Amendment." University of Pennsylvania Law Review 138 (1989): 437-504.

Uggen, Christopher. "Work as a Turning Point in the Life Course of Criminals." American Sociological Review 65, no. 4 (2000): 529-46.

Wacquant, Loïc. Punishing the Poor: The Neoliberal Government of Social Insecurity. Durham, NC: Duke University Press, 2009.

. "Prisoner Reentry as Myth and Ceremony." Dialectical Anthropology 34, no. 4 (2010): 605-20.

Watkins, D. "Poor Black People Don't Work?: Lessons of a Former Dope Dealer." Salon, April 22, 2014. http://www.salon.com/2014/04/22/poor_black_people_dont_work_lessons_of_a_former_ dope_dealer/.

Weil, David. The Fissured Workplace: Why Work Became So Bad for So Many and What Can Be Done to Improve It. Cambridge, MA: Harvard University Press, 2014.

Weisburd, David, Tomer Einat, and Matt Kowalski. "The Miracle of the Cells: An Experimental Study of Interventions To Increase Payment of Court-ordered Financial Obligations." Criminology Eु Public Policy 7, no. 1 (2008): 9-36.

Weiss, Robert P. "'Repatriating' Low-Wage Work: The Political Economy of Prison Labor Reprivatization in the Postindustrial United States." Criminology 39, no. 2 (2001): 253-92.

Western, Bruce. Punishment and Inequality in America. New York: Russell Sage Foundation, 2006.

- From Prison to Work: A Proposal for a National Prisoner Reentry Program. Brookings Institution, 2008.

Western, Bruce, and Katherine Beckett. "How Unregulated Is the U.S. Labor Market? The Penal System as a Labor Market Institution." American Journal of Sociology 104, no. 4 (1999): 1030-60.

Williams, Lucy A. "Unemployment Insurance and Low Wage Work." In Hard Labor: Women and Work in the Post-Welfare Era. Edited by Joel F. Handler and Lucie White, 158-74. Armonk, NY: M.E. Sharpe, 1999.

Wilson, William Julius. When Work Disappears. New York: Vintage, 1996.

Wright, Erik Olin. "Basic Income, Stakeholder Grants, and Class Analysis." Politics Society 32, no. 1 (2004): 79-87.

Zatz, Noah D. "What Welfare Requires from Work." UCLA Law Review 54, no. 2 (2006): 373-464.

- "Working at the Boundaries of Markets: Prison Labor and the Economic Dimension of Employment Relationships." Vanderbilt Law Review 61, no. 3 (2008): 857-958.

"Poverty Unmodified?: Critical Reflections on the Deserving/Undeserving Distinction." UCLA Law Review 59, no. 3 (2012): 550-97.

"A New Peonage?: Pay, Work, or Go To Jail in Contemporary Child Support Enforcement and Beyond." Seattle Law Review 39, no. 3 (2016): 927-55.

"The Carceral State at Work: Exclusion, Coercion, and Subordination." In Criminality at Work. Edited by Alan Bogg, Jennifer Collins, Mark Freedland, and Jonathan Herring. New York: Oxford University Press, forthcoming.

Zatz, Noah D., and Eileen Boris. "Seeing Work, Envisioning Citizenship." Employee Rights and Employment Policy Journal 18 (2014): 95-109.

Zatz, Noah D., and Michael A. Stoll. "Working to Avoid Incarceration: Jail Threat and Labor Market Outcomes for Noncustodial Fathers Facing Child Support Enforcement." RSF: The Russell Sage Foundation Journal of the Social Sciences 6 (forthcoming 2020). 
Zatz, Noah D., Tia Koonse, Theresa Zhen, Lucero Herrera, Han Lu, Steven Shafer, and Blake Valenta. Get To Work or Go To Jail: Workplace Rights Under Threat. UCLA Institute for Research on Labor and Employment, UCLA Labor Center, and A New Way of Life Reentry Project, 2016.

Zelizer, Viviana A. The Social Meaning of Money: Pin Money, Paychecks, and Other Currencies. Princeton, NJ: Princeton University Press, 1997.

- The Purchase of Intimacy. Princeton, NJ: Princeton University Press, 2005.

Zhen, Theresa. "How Ability-to-Pay Determinations Are Inadequate to Transform a Racialized System of Penal Debt." New York University Review of Law E⿱ Social Change 43, no. 1 (2019): $175-222$.

\section{CASES CITED}

Anderson v. Ellington, 300 F. Supp. 789 (M.D. Tenn. 1969)

Batton v. Com. ex rel. Noble, 369 S.W.3d 722 (Ky. Ct. App. 2012)

Bearden v. Georgia, 461 U.S. 660 (1983)

Bennett v. Frank, 395 F.3d 409 (7th Cir. 2005)

City of Wichita v. Lucero, 874 P.2d 1144 (Kan. 1994)

Commissioner of Social Services v. Rosen, 736 N.Y.S.2d. 42 (App. Div. 2001)

Doyle v. City of New York, 91 F. Supp.3d 480 (S.D.N.Y. 2015)

McDaniel v. McDaniel, 878 So. 2d 686 (La. Ct. App. 2004)

Moss v. Superior Court, 950 P.2d 59 (Cal. 1998)

People v. Likine, 823 N.W.2d 50 (Mich. 2012)

Schmeets v. Turner, 706 S.W.2d 504 (Miss. Ct. App. 1986)

State v. Brady, 300 P.3d 778 (Utah Ct. App. 2013)

State v. Ingram, 142 P.3d 338 (Kan. Ct. App. 2016)

Toney v. State, 37 So. 332 (Ala. 1904)

Turner v. Rogers, 564 U.S. 431 (2011)

United States v. Bailey, 219 U.S. 219 (1911)

United States v. Ballek, 170 F.3d 871 (9th Cir. 1999)

United States v. City of New York, 359 F.3d 83 (2d Cir. 2004)

United States v. Kozminski, 487 U.S. 931 (1988)

Vanskike v. Peters, 974 F.2d 810 (7th Cir. 1992)

Williams v. Illinois, 399 U.S. 235 (1970)

\section{STATUTES CITED}

Fair Labor Standards Act, 29 U.S.C. § 203 (1938)

Personal Responsibility and Work Opportunity Reconciliation Act of 1996, 42 U.S.C. $\S 666$

Cal. Penal Code $\S 1209.5$

Cal. Veh. Code $\S 42003$

Louisiana C. Cr. P. § 875.1

Mont. St. Ann. § 40-5-291

N.Y. Crim. Proc. Law $§ 170.55$

Ohio Rev. Code 3119.06

56 Okla. St. Ann. § 240.10 